\title{
Simulated Interannual Variations of the Indo-Australian Monsoons
}

\author{
By Akio Kitoh \\ Meteorological Research Institute, Tsukuba, Ibaraki 305, Japan \\ (Manuscript received 5 July 1991, in revised form 18 November 1991)
}

\begin{abstract}
Interannual variations of the South Asian and the Australian summer monsoons in a 20-year simulation by an atmospheric general circulation model (GCM) with the observed sea surface temperature (SST) for the period 1970-1989 are investigated. Emphasis is laid on moisture flux variations, as the moisture flux convergence plays a more dominant role in the rainfall variations than the local evaporation, although their relative roles are comparable for the 20-year mean moisture budget.

The anomalous precipitation in the Bay of Bengal in boreal summer is significantly correlated with the SST anomalies in the western Pacific, but not with the in situ SST anomalies. The positive SST anomalies in the western Pacific are favorable to the intensified South Asian summer monsoon circulation with strong surface westerlies over the north Indian Ocean. A contrast in anomalous precipitation in the model between the South Arabian Sea and the India subcontinent is also discussed. The anomalous precipitation over the oceans north of Australia in austral summer is explained mainly by the anomalous moisture flux converging into this region from the west. This is accompanied by an intensified cyclonic circulation northwest of Australia, but cross-equatorial moisture flux from the winter hemisphere is found to be important. Some comparisons with observations are also made and discrepancies between the model and these observation are discussed.
\end{abstract}

\section{Introduction}

The diabatic heating due to condensation in the tropics forms a major part of the atmospheric heat engine. In particular, the convective heating in South Asia and the maritime continent (Indonesia to New Guinea region) is dominant in the world in its strength as well as in its spatial scale. Therefore, the Asian summer monsoon and the Australian summer monsoon play an important role in establishing the climate system not only in this region but worldwide (Krishnamurti and Surgi, 1987; McBride, 1987). It is widely known that there is a large interannual variation in these monsoons not only in their intensity but also in duration and the date of onset (e.g., Mooley and Shukla, 1987a; Holland, 1986; Joseph et al., 1991). Large changes in the intensity or zonal/meridional shift of the monsoon activity could result in non-local circulation changes.

Attempts have been made to simulate the monsoons by atmospheric general circulation models (GCMs) for many years (e.g., Gilchrist, 1977; Washington, 1981; Krishnamurti, 1987). Recently, there has been vigorous activity in monsoon climate research in numbers of institutes and universities in association with the Monsoon Numerical Experimentation Group MONEG (WMO, 1990). The lower-

(C)1992, Meteorological Society of Japan resolution GCMs generally fail to simulate the smallscale precipitation pattern because the small-scale topography can not be incorporated in the model and these models do not handle important rainproducing features such as monsoon depressions. In spite of those limitations, the lower-resolution GCMs can reproduce the basic monsoon circulations and are suitable for studying interannual variations of the monsoons by performing decades of integrations. A number of GCM studies are performed to investigate the impact of $\mathrm{El} \mathrm{Niño/La}$ Niña sea surface temperature (SST) anomalies and many succeed in simulating atmospheric anomalies in the tropical Pacific (e.g., Lau, 1985; Nihoul, 1985; WMO, 1986).

Kitoh (1991) describes the interannual variations of the tropical atmosphere simulated by the Meteorological Research Institute (MRI) GCM with the prescribed interannually varying SST over the period 1970-1989. The MRI GCM is shown to reproduce the observed eastward propagation of the zonal surface stress anomalies in the equatorial $\mathrm{Pa}-$ cific responding to the prescribed SST changes. In the present study we investigate interannual variations of the summer monsoons in the IndoAustralian region in the June-July-August (JJA) and the December-January-February (DJF) seasons, respectively. Emphasis of the analysis is laid on 

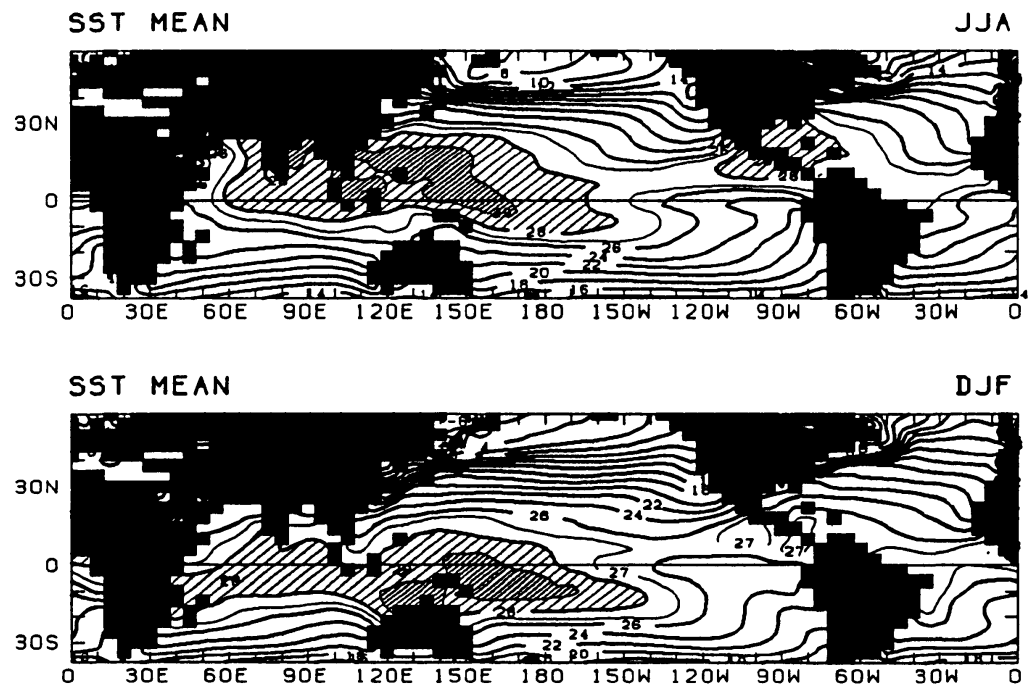

Fig. 1. The climatological SST for (top) JJA and (bottom) DJF in the 20-year period 1970-1989. The contour interval is $2^{\circ} \mathrm{C}$. The contours for $27^{\circ} \mathrm{C}$ and $29^{\circ} \mathrm{C}$ are drawn with thin lines. Values greater than 28 and 29 are hatched lightly and heavily, respectively.

moisture flux variations because the moisture flux convergence plays a dominant role over the local evaporation on the interannual precipitation variability. A direct comparison between the simulated and observed interannual monsoon variations has a limit due to the model's inability to simulate smallscale rain-producing systems and to the model's systematic errors. However, it will be shown that a current GCM is still a useful tool to get some insight into the interannual variations in the tropical atmosphere.

\section{The model integration}

The model (MRI AGCM) used for this study is a 5 -level atmospheric general circulation model. The model is of grid representation with a horizontal resolution of $5^{\circ}$ longitude and $4^{\circ}$ latitude with a top at $100 \mathrm{mb}$. Physical processes included are the parameterized cumulus convection, planetary boundary layer (PBL), radiation that is interactive with model-generated cloud. Ground hydrology parameterization predicts snow mass and ground soil moisture. Diurnal as well as seasonal variation of insolation is included. Details of this model (MRI GCMI) are described in Tokioka et al. (1984). Some modifications have been made to the MRI GCM-I. The current MRI AGCM uses a modified ArakawaSchubert penetrative cumulus convection (Tokioka et al., 1988), seasonally and geographically dependent surface albedo compiled by Matthews (1983), increased surface drag by sub-grid scale topography (Yagai and Tokioka, 1987), and latitude-dependent field capacity. See Kitoh (1991) for details.

The model has been integrated for 20.5 years from September 1969 to February 1990 with the prescribed SST over the oceans for $40^{\circ} \mathrm{S}-60^{\circ} \mathrm{N}$ (the ob- served SST run). The SST data come from the Climate Analysis Center/NOAA before 1984 and from the Japan Meteorological Agency after 1985. Polewards of these latitudes we use the climatological SST of Alexander and Mobley (1976). For the sea ice distributions, a climatological seasonal change is prescribed. We have made a parallel 20.5 year integration that removed the interannual variation of the SST (the climatological SST run), whose results are also used.

The Asian summer monsoon climate in the climatological SST run is compared with the observation in Bhaskar Rao et al. (1991) and a detailed analysis of the interannual variations of the Pacific tropical atmosphere of the observed SST run is reported by Kitoh (1991).

For the reader's convenience, we begin with the SST fields. Figure 1 shows the climatological SST for JJA and DJF. Warm SST areas above $28^{\circ} \mathrm{C}$ are found in the tropical western Pacific and in the tropical Indian Ocean. They show a seasonal meridional migration with the warmest $\mathrm{SST}$ region above $29^{\circ} \mathrm{C}$ north of the equator in JJA and south of the equator in DJF in the maritime continent. The ocean around Central America is covered with warm water above $28^{\circ} \mathrm{C}$ in JJA. A "cold tongue" in the eastern equatorial Pacific is stronger in JJA than in DJF. A meridional SST gradient between the cold tongue and the warm SST belt around $10^{\circ} \mathrm{N}$ is also the largest in JJA. Actually, the cold tongue is strongest in September.

Figure 2 shows the standard deviation of the seasonal mean SST for JJA and DJF in the 20-year period used in the experiment. Large SST variations related to El Niño appear in the central and eastern equatorial Pacific. The area with the largest SST 

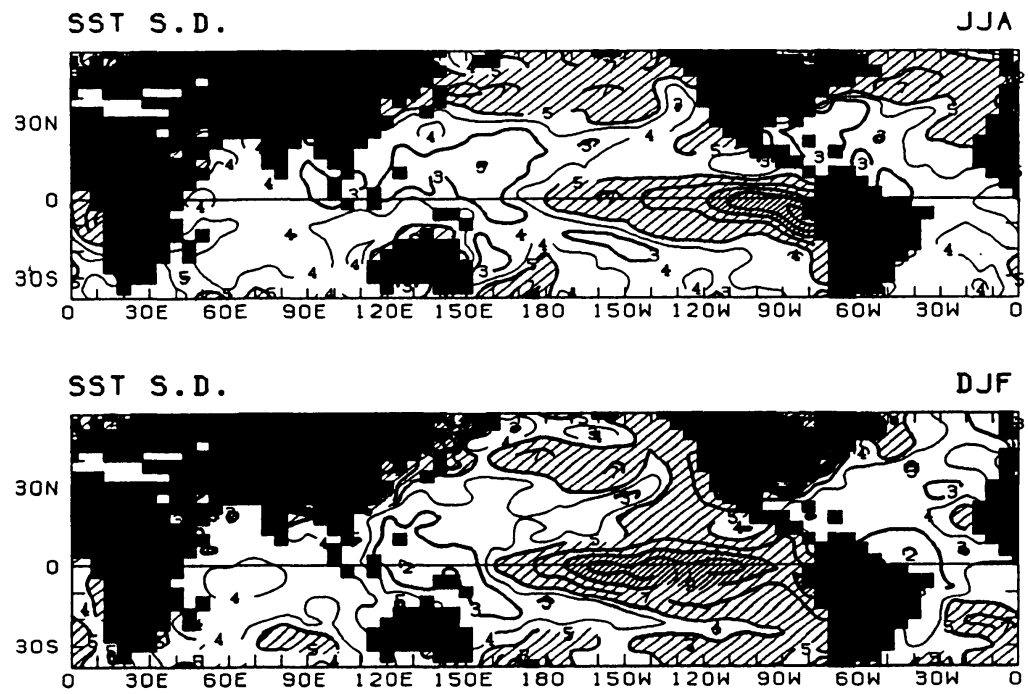

Fig. 2. The interannual standard deviation of the seasonal mean SST for (top) JJA and (bottom) DJF in the 20-year period $1970-1989$. The unit is $0.1^{\circ} \mathrm{C}$. The contour interval is 2 . The contours for 4 are drawn with thin lines. Values greater than 5 and 9 are hatched lightly and heavily, respectively.

variation varies with season. It is in the far eastern Pacific off the coast of South America in JJA, while it is located around $140^{\circ} \mathrm{W}$ in DJF. In other parts of the tropical oceans, the SST variability is rather small. It is the smallest in the western tropical Pacific.

Figure 3 shows the time-series of the monthly mean precipitation anomalies for the South Arabian Sea, the Indian subcontinent, the Bay of Bengal, the Australian monsoon region in the 20 -year observed SST run. They are three $15^{\circ} \times 12^{\circ}$ oceanic areas where there is large precipitation variability and a land area corresponding in size to India. These regions are indicated with dashed lines in Figs. 8, 9, 10 and 14. The observed SST anomaly for the NINO3 region $\left(150^{\circ} \mathrm{W}-90^{\circ} \mathrm{W}, 4^{\circ} \mathrm{S}-4^{\circ} \mathrm{N}\right)$ is also included as a reference of the tropical SST changes. The climatology for each month is removed from the original monthly mean data. Five-month running means are displayed by thick lines.

The simulated monthly mean precipitation is highly variable from month to month. In some years there is a large change of the precipitation anomalies from large positive to large negative values (or the other way) even in one season. For example, the precipitation anomaly in the Australian summer monsoon region in December 1978 is $+4.3 \mathrm{~mm} \mathrm{~d}^{-1}$ but it changed to $-6.8 \mathrm{~mm} \mathrm{~d}^{-1}$ in the next month. An opposite change occurred between December 1988 $(-4.1)$ and January $1989(+6.0)$. This intraseasonal variation is an important aspect of the monsoon circulations not only in the Australian summer monsoon (e.g., Hendon and Liebmann, 1990) but also in the Asian summer monsoon (e.g., Yasunari, 1979). However, this paper focuses on how the atmosphere responds to the slowly varying imposed SST, with particular interest on the interannual variation of the seasonal mean monsoon circulations. Therefore, the intraseasonal variations in the simulated monsoon will be left to further studies and only the seasonal means are analyzed in this paper.

\section{The Asian summer monsoon}

\section{a. Precipitation}

Figure 4 shows the 20-year mean JJA precipitation and its standard deviation in the observed SST run. There are large precipitation areas in the Asian summer monsoon region over the South Arabian Sea and the Bay of Bengal, in Central Africa, Central America and the Intertropical Convergence Zone (ITCZ). The model overestimates the precipitation in the North Indian Ocean compared with observations (Jaeger, 1976). Over southern India, the precipitation is greater on the windward western side of the subcontinent along the western Ghats than on the eastern side. An intense rainfall observed at the foothill of the Himalayas, which is highly influenced by local topography, is not reproduced in this model (Kitoh and Tokioka, 1986; Bhaskar Rao et $a l ., 1991)$. It clearly shows the greater precipitation over land compared with the surrounding oceans in the Indochina peninsula and over the islands of Indonesia and the Philippines.

The interannual variability in precipitation is particularly large over the South Arabian Sea and the Bay of Bengal. It is moderate over the Indian subcontinent and the Indochina peninsula. The interannual variability in the monsoon precipitation over land is less than that over the ocean. All areas with a standard deviation greater than $2 \mathrm{~mm} \mathrm{~d}^{-1}$ are situated over the oceans and not over land, although the mean precipitation is large over land in South 

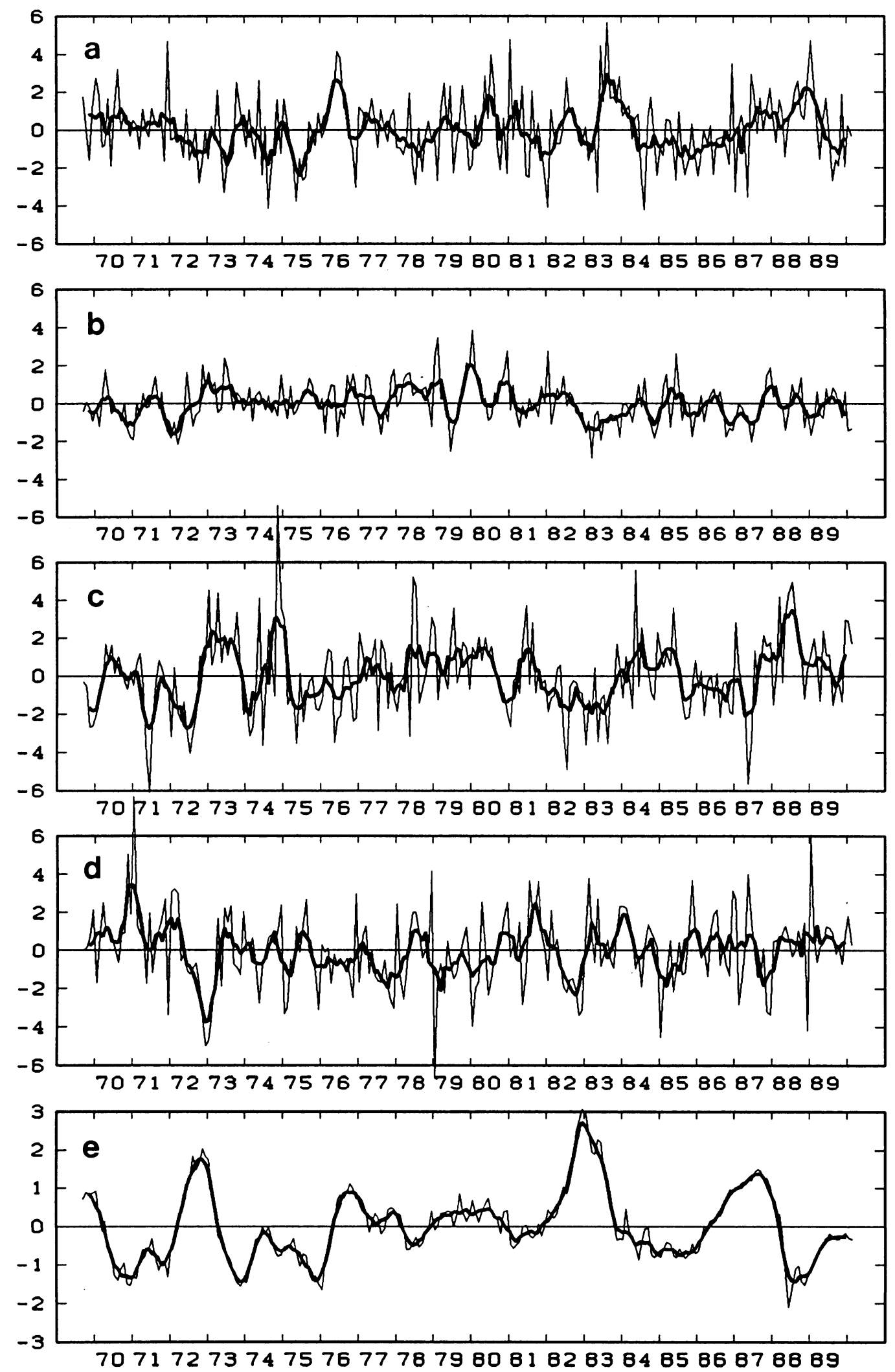

Fig. 3. Time-series of monthly-mean anomalies for the simulated precipitation $\left(\mathrm{mm} \mathrm{d}^{-1}\right)$ in (a) the South Arabian Sea, (b) the Indian subcontinent, (c) the Bay of Bengal, (d) the Australian summer monsoon region, and (e) the observed sea surface temperature $\left({ }^{\circ} \mathrm{C}\right)$ in the NINO3 region. See text for the definition of the averaged area. Original monthly means are plotted by thin lines and 5-month running means are shown by thick lines. 

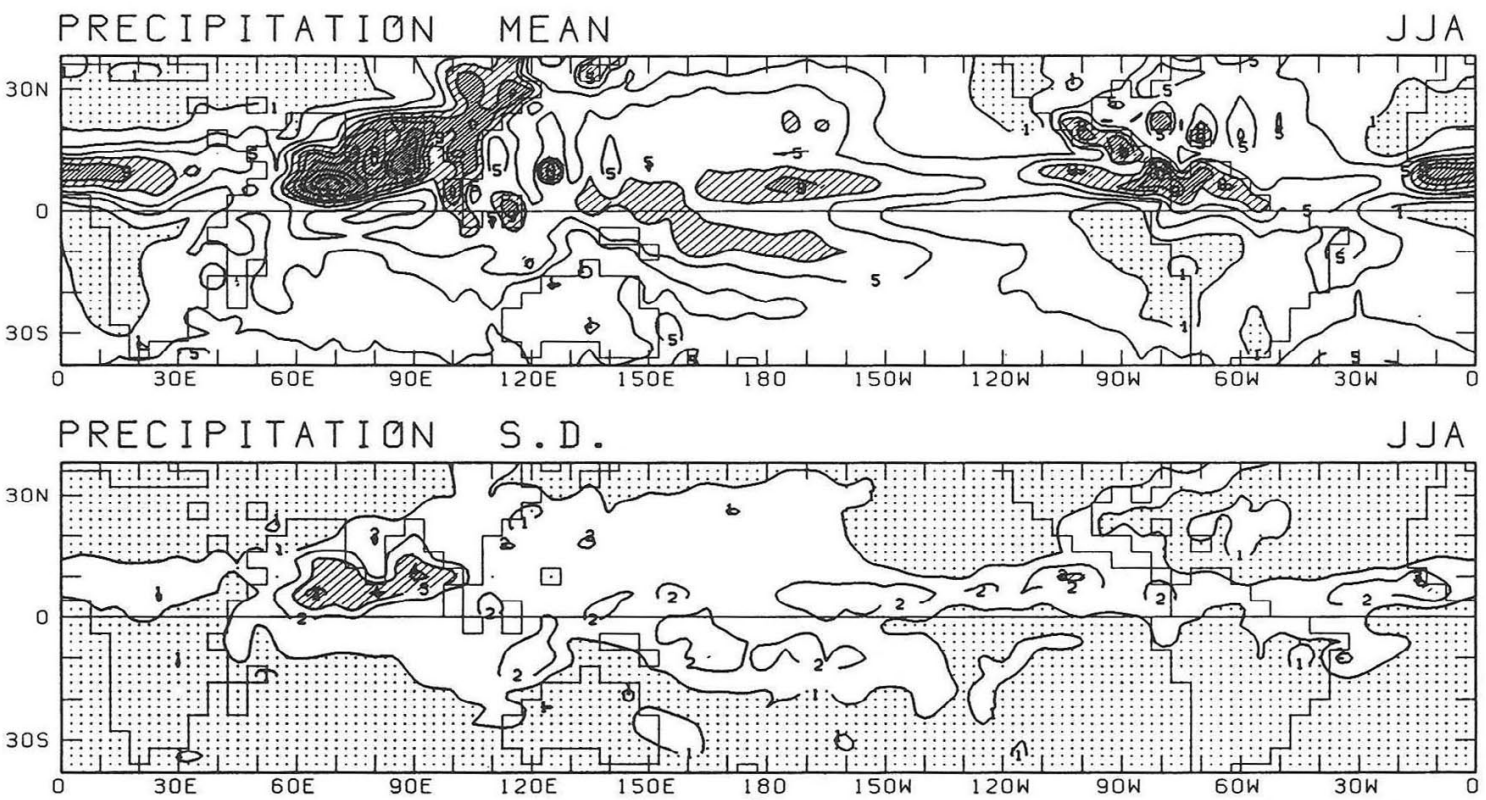

Fig. 4. (top) 20-year means of the simulated JJA precipitation in the observed SST run. The contour interval is $2 \mathrm{~mm} \mathrm{~d}^{-1}$. Values greater than 7,9 and 13 are hatched with increasing density and values less than 1 are dotted. (bottom) Standard deviation of the simulated JJA precipitation. The contour interval is $1 \mathrm{~mm} \mathrm{~d}^{-1}$. Values greater than 3 are hatched and values less than 1 are dotted.
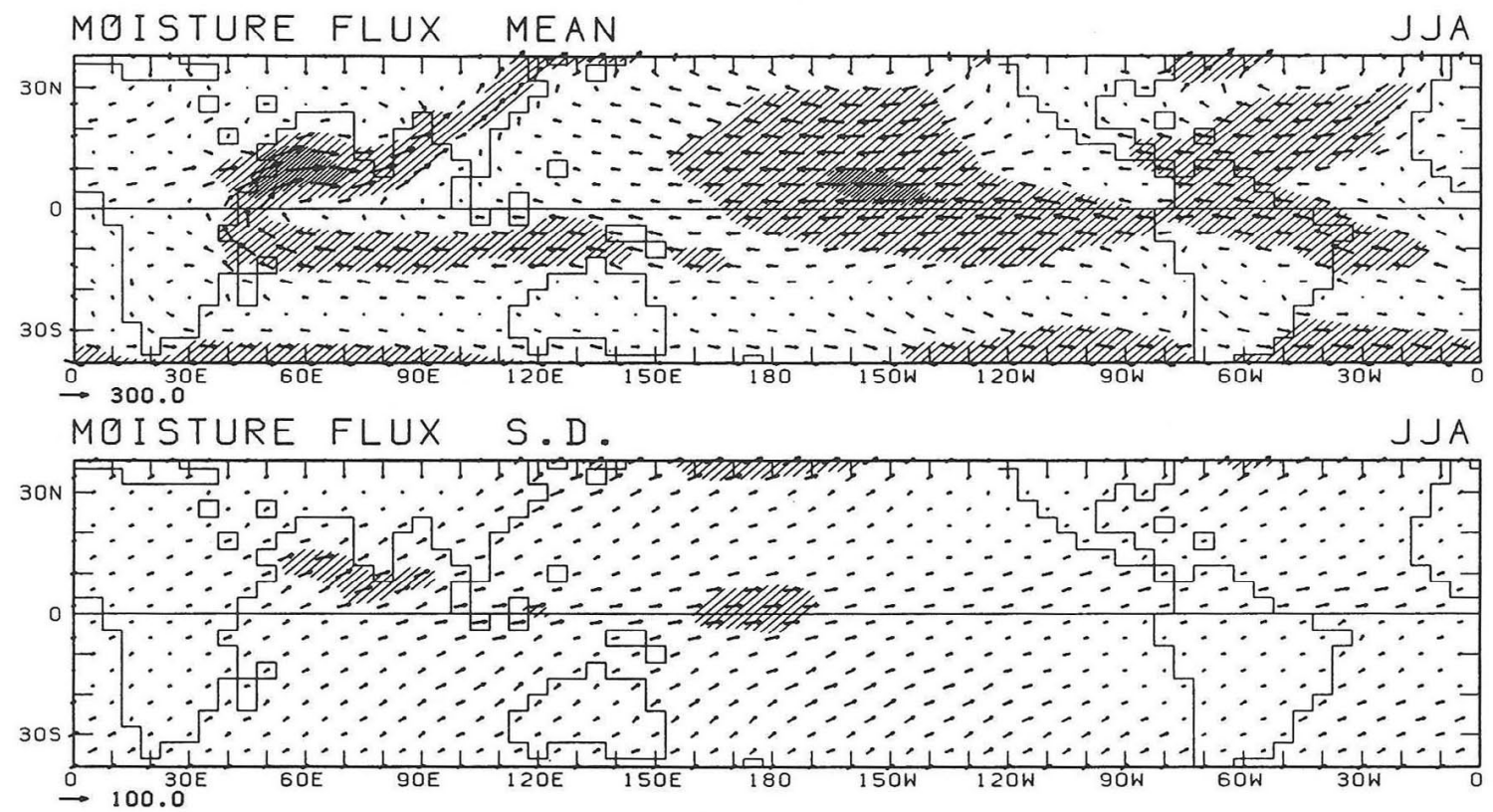

Fig. 5. As in Fig. 4 except for the total moisture flux. The reference vector is (top) 300 and (bottom) 100 $\mathrm{kg} \mathrm{m}^{-1} \mathrm{~s}^{-1}$. Regions with magnitude greater than 150 and 300 (50 and 100) in the top (bottom) panel are hatched lightly and heavily, respectively.

Asia, Central America and Central Africa. This relatively smaller variability in precipitation over land, in spite of its larger mean values, is also seen in the climatological SST run, where there is no interannual variation in the imposed SST (not shown). The observed outgoing longwave radiation (OLR) data shows larger standard deviations over the oceans than over land, both in the interannual variation and in the intraseasonal variation (Kawahara, 1990).

\section{b. Moisture flux}

Figure 5 shows the JJA mean total column moisture flux. Zonal and meridional components are calculated separately and are shown in the vector for- 
Table 1. The simulated 20-year seasonal mean precipitation $(\mathrm{P})$, evaporation $(\mathrm{E})$ and its difference $(\mathrm{P}-\mathrm{E})$ and their standard deviations in the observed SST run and the climatological SST run for the South Arabian Sea, the Indian subcontinent, the Bay of Bengal for the June-July-August season and for the Australian monsoon region for the December-January-February season. Regions are defined as follows: South Arabian Sea $\left(57.5^{\circ} \mathrm{E}-72.5^{\circ} \mathrm{E}, 0^{\circ} \mathrm{N}-12^{\circ} \mathrm{N}\right)$; Indian subcontinent (eight $5^{\circ} \times 4^{\circ}$ land grid points in $\left.72.5^{\circ} \mathrm{E}-87.5^{\circ} \mathrm{E}, 8^{\circ} \mathrm{N}-24^{\circ} \mathrm{N}\right)$; Bay of Bengal $\left(82.5^{\circ} \mathrm{E}-97.5^{\circ} \mathrm{E}, 4^{\circ} \mathrm{N}-16^{\circ} \mathrm{N}\right)$; Australian monsoon $\left(122.5^{\circ} \mathrm{E}-137.5^{\circ} \mathrm{E}, 12^{\circ} \mathrm{S}-0^{\circ} \mathrm{S}\right)$.

\begin{tabular}{|c|c|c|c|c|c|c|c|c|c|c|c|c|}
\hline & \multicolumn{6}{|c|}{ observed SST run } & \multicolumn{6}{|c|}{ climatological SST run } \\
\hline & \multicolumn{3}{|c|}{ mean } & \multicolumn{3}{|c|}{ s.d. } & \multicolumn{3}{|c|}{ mean } & \multicolumn{3}{|c|}{ s.d. } \\
\hline region & $\mathrm{P}$ & $\mathrm{E}$ & $\mathrm{P}-\mathrm{E}$ & $\mathrm{P}$ & $\mathrm{E}$ & $\mathrm{P}-\mathrm{E}$ & $\mathrm{P}$ & $\mathrm{E}$ & $\mathrm{P}-\mathrm{E}$ & $\mathrm{P}$ & $\mathrm{E}$ & $\mathrm{P}-\mathrm{E}$ \\
\hline South Arabian Sea & 12.58 & 6.14 & 6.43 & 1.72 & 0.57 & 1.31 & 12.52 & 5.92 & 6.60 & 0.87 & 0.15 & 0.83 \\
\hline Indian subcontinent & 10.30 & 5.64 & 4.65 & 0.82 & $\overline{0.19}$ & 0.72 & 10.09 & 5.62 & 4.47 & 0.50 & 0.15 & 0.45 \\
\hline Bay of Bengal & 10.79 & 5.60 & 5.19 & 1.94 & 0.45 & 1.54 & 9.53 & 5.38 & 4.15 & $\overline{0.89}$ & 0.21 & 0.73 \\
\hline Australian monsoon & 10.79 & 5.60 & 5.19 & 1.71 & 0.59 & 1.20 & 11.11 & 5.58 & 5.53 & 0.95 & 0.31 & 0.76 \\
\hline
\end{tabular}

Note: The same values of the 20-year means for the Bay of Bengal and the Australian monsoon region in the observed SST run occurred by accident.

mat. The mean moisture flux roughly corresponds to the lower tropospheric wind flow. In the tropics, the easterly trade winds and the southwesterly South Asian monsoon flow are captured by the model. The latter is dominant in the region from the Arabian Sea, through southern India, to the Indochina peninsula. The failure in representing the narrow and high Burma mountains in the Indochina peninsula due to the coarse horizontal resolution of the model facilitates a penetration of the moisture flux from the Bay of Bengal through the peninsula into South China, resulting in larger-than-observed precipitation there (Fig. 4). The South Asian monsoon flow is connected with the easterly flow in the Indian Ocean south of the equator by the crossequatorial flow with its maximum at the east coast of Africa. The southwesterly flow of the African monsoon also joins the South Asian monsoon flow at the location of the Somali jet. The magnitude of the simulated moisture flux is smaller than the observed value (not shown). Both a weaker lower tropospheric wind and a smaller moisture content in the lower troposphere contribute to this difference.

The interannual variability of the moisture flux is large over the North Indian Ocean and over the equatorial central Pacific. Over the equatorial Pacific, it is almost in the zonal direction, while there are considerable meridional components in the South Arabian Sea and the Bay of Bengal.

\section{c. Moisture budgets in selected key regions}

We picked out 3 key regions in the South Asian monsoon area. The two are the $15^{\circ} \times 12^{\circ}$ areas in the South Arabian Sea $\left(57.5^{\circ} \mathrm{E}-72.5^{\circ} \mathrm{E}, 0^{\circ} \mathrm{N}-12^{\circ} \mathrm{N}\right)$ and in the Bay of Bengal $\left(82.5^{\circ} \mathrm{E}-97.5^{\circ} \mathrm{E}, 4^{\circ} \mathrm{N}-16^{\circ} \mathrm{N}\right)$ where the interannual variation in precipitation is the largest. The average in the Indian subconti- nent (eight $5^{\circ} \times 4^{\circ}$ grid points shown in Fig. 9) is also made. Table 1 shows the mean and the standard deviation of the seasonal mean precipitation $(\mathrm{P})$, evaporation $(\mathrm{E})$ and its difference $(\mathrm{P}-\mathrm{E})$ for the 3 key regions obtained in the observed SST run and the climatological SST run. The P-E can be considered as the moisture flux convergence in this time-scale.

It is shown that, for the 20-year means, contributions from the local evaporation and the moisture flux convergence $(\mathrm{P}-\mathrm{E})$ are of comparable magnitude for all three regions. However, the interannual variation of the precipitation is mainly caused by changes in the moisture flux convergence. For example, over the Bay of Bengal, the composite difference of the precipitation for 3 large precipitation years (1988, 1978 and 1981) and 3 small precipitation years $\left(1972,1971\right.$ and 1982) is $3.04 \mathrm{~mm} \mathrm{~d}^{-1}$. The local evaporation consists of only $0.72 \mathrm{~mm} \mathrm{~d}^{-1}$ and the moisture flux convergence accounts for the rest with $2.32 \mathrm{~mm} \mathrm{~d}^{-1}$.

Figure 6 shows the $\mathrm{P}$ to $\mathrm{E}$ ratio of their standard deviations. In almost the entire tropics, the value is greater than 2 and the moisture flux convergence is the major factor in the precipitation variability. The only exception is found over the eastern equatorial Pacific and over the Atlantic in the DJF season. The mid-latitude ocean is the region where the change in the local evaporation mainly explains the precipitation variability.

Table 1 also confirms smaller standard deviations in $\mathrm{P}, \mathrm{E}$ and $\mathrm{P}-\mathrm{E}$ in the Indian subcontinent compared with the other two key regions (Fig. 4). It is about a half of that in the surrounding oceans.

The 20-year mean P, E and P-E in the climatological SST run are not so different from those in the observed SST run. The only significant difference in Table 1 between the observed SST run and the 

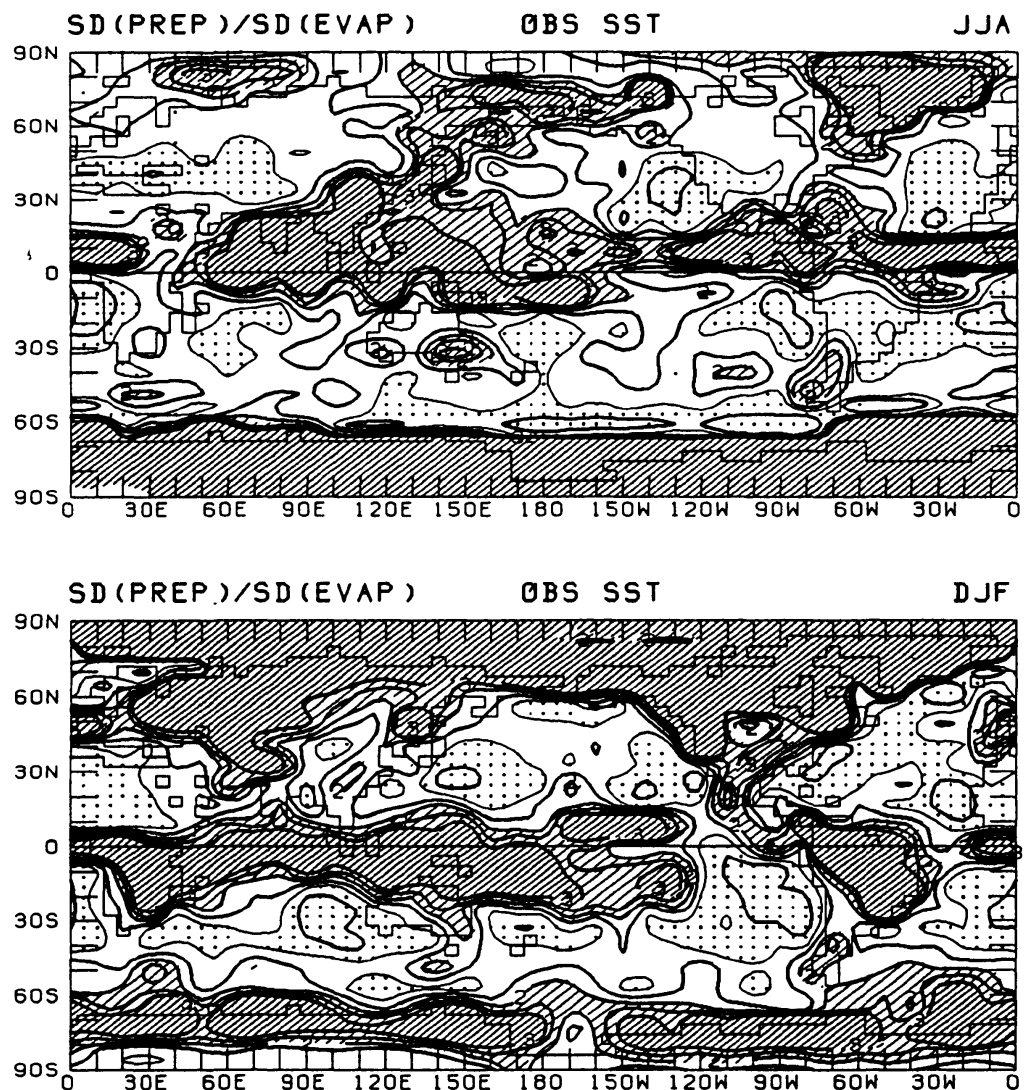

Fig. 6. Ratio of the standard deviation of the seasonal mean precipitation to that of the evaporation in the observed SST run for (top) JJA and (bottom) DJF. The contour interval is 0.5. Values greater than 2 are hatched and values less than 1 are dotted. Values greater than 3 are not contoured.

climatological SST run is $\mathrm{P}$ and $\mathrm{P}-\mathrm{E}$ in the Bay of Bengal. An analysis of the significant differences between the observed SST run and the climatological SST run remains to be a further study, but the nonlinear relationship between the absolute SST and convective activity is one possible candidate.

On the contrary, the magnitude of the standard deviations is quite different between the two experiments. The observed SST run has about twicelarger standard deviations of $\mathrm{P}, \mathrm{E}$ and $\mathrm{P}-\mathrm{E}$ in the key regions. The increase of the atmospheric variability by using the observed SST instead of the climatological one is demonstrated by Lau (1985). The geographical distribution of the increase of the standard deviations in seasonal mean precipitation due to the use of the observed SST is shown in Fig. 7. The increase of the interannual variability in precipitation by using the observed SST is very large in the central and eastern tropical Pacific, where the interannual SST variation is the largest. Reflecting the seasonal change (shift) of the observed SST variation pattern (Fig. 2), the increase of precipitation variability is the largest in the eastern Pacific in JJA, while it is in the central Pacific in DJF. The increase of the interannual variability in precipitation is larger in the DJF season when El Niño/La
Niña SST variations meet their peak values. It is noted that, in the tropics, the atmospheric variability increases modestly over the western Pacific, over the Indian Ocean and over the Atlantic by using the observed SST. This is because the interannual SST variability is smaller in these oceans than in the central and eastern equatorial Pacific (see Fig. 2).

\section{$d$. Interannual variation}

In this subsection, we investigate the interannual variations of the simulated precipitation in the South Arabian Sea, the Indian subcontinent and the Bay of Bengal by using composite maps. We show the difference between the heavy precipitation years and the light precipitation years of the reference region.

\section{1) SOUTH ARABIAN SEA}

Figure 8 shows the anomalous precipitation, the evaporation, the SST, and the moisture flux and its convergence/divergence composited concerning the precipitation in the South Arabian Sea. Data for 3 years with the largest precipitation $(1983,1976$ and 1980 model year) and 3 years with the least precipitation (1973, 1975 and 1974) are composited. The simulated ground temperature is substituted 

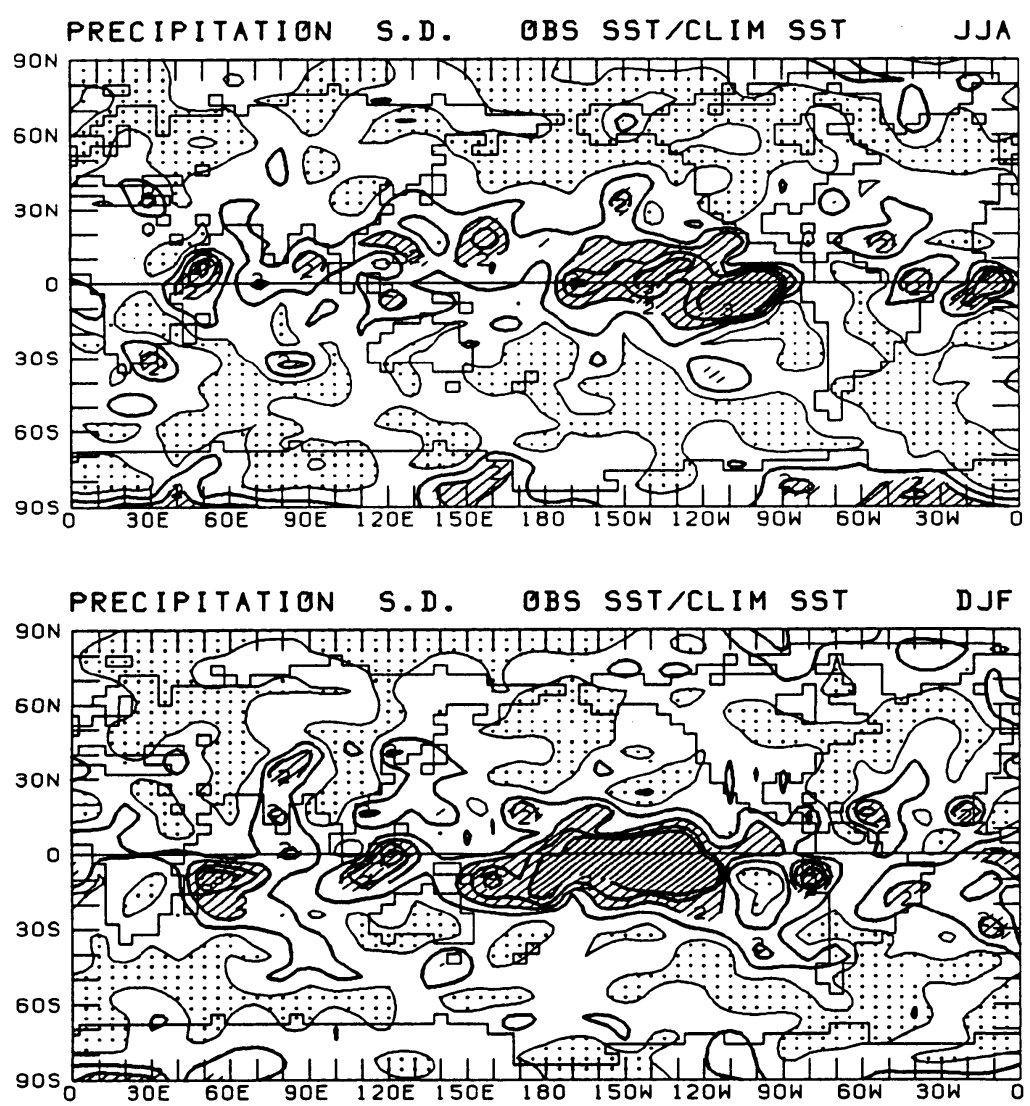

Fig. 7. Ratio of the standard deviation of the simulated precipitation in the observed SST run to that in the climatological SST run for (top) JJA and (bottom) DJF. The contour interval is 0.5. Values greater than 2 are hatched and values less than 1 are dotted. Values greater than 3 are not contoured.

over the land grid points for the SST map. The simultaneous correlation is also calculated using the seasonal mean anomalies between the South Arabian Sea precipitation and the global precipitation, evaporation and SST anomalies. When they are significant at the $95 \%$ confidence level (correlations greater than 0.47 with $n=20$ ), those grid points are marked in the figure.

When the anomalous precipitation over the South Arabian Sea is positive, that over the tropical Indian Ocean southeast of the reference area tends to be positive, but that is not significantly correlated. There is a significant positively correlated region in the eastern equatorial Pacific. In the western Pacific, there are small negative anomalies. This anomaly pattern roughly reflects the El Niño-related interannual variation of the SSTs. It is noted that the precipitation in the Indian subcontinent tends to correlate negatively with that in the South Arabian Sea. The evaporation anomaly is positive and significant over the reference area, but its magnitude is very small compared to the precipitation anomaly as already discussed.

The composite/correlation map for the SST shows large areas with significant correlation with the precipitation in the South Arabian Sea. The correlation is significantly positive over the Arabian Sea and the tropical Indian Ocean, as well as over the eastern $\mathrm{Pa}$ cific. The fact that the spatial scale for the SST is larger than that for the precipitation indicates the localization of the precipitation phenomenon.

On the interannual time-scale, the Indian Ocean SST and the eastern Pacific SST are generally well correlated. This results in a significant remote correlation in Fig. 8c. Table 2a shows the lagged correlations between the seasonal mean precipitation in the South Arabian Sea and the NINO3 SST. For this calculation, all seasons' data are used without distinction. The maximum positive correlation is found when the precipitation lags the NINO3 SST for 3 seasons and a large negative correlation is obtained when the precipitation leads the SST for 4 to 5 seasons. As the South Arabian Sea precipitation is sensitive to the in situ SST in the model, this reflects a time-lag between the NINO3 SST and the Indian Ocean SST and a 3 to 4 year periodicity of the SST variation. This lagged correlation reflects the fact that the Indian Ocean SST lags the eastern tropical Pacific SST.

The map for the moisture flux shows a large easterly anomaly over the maritime continent and a westerly anomaly west of the reference area. When 


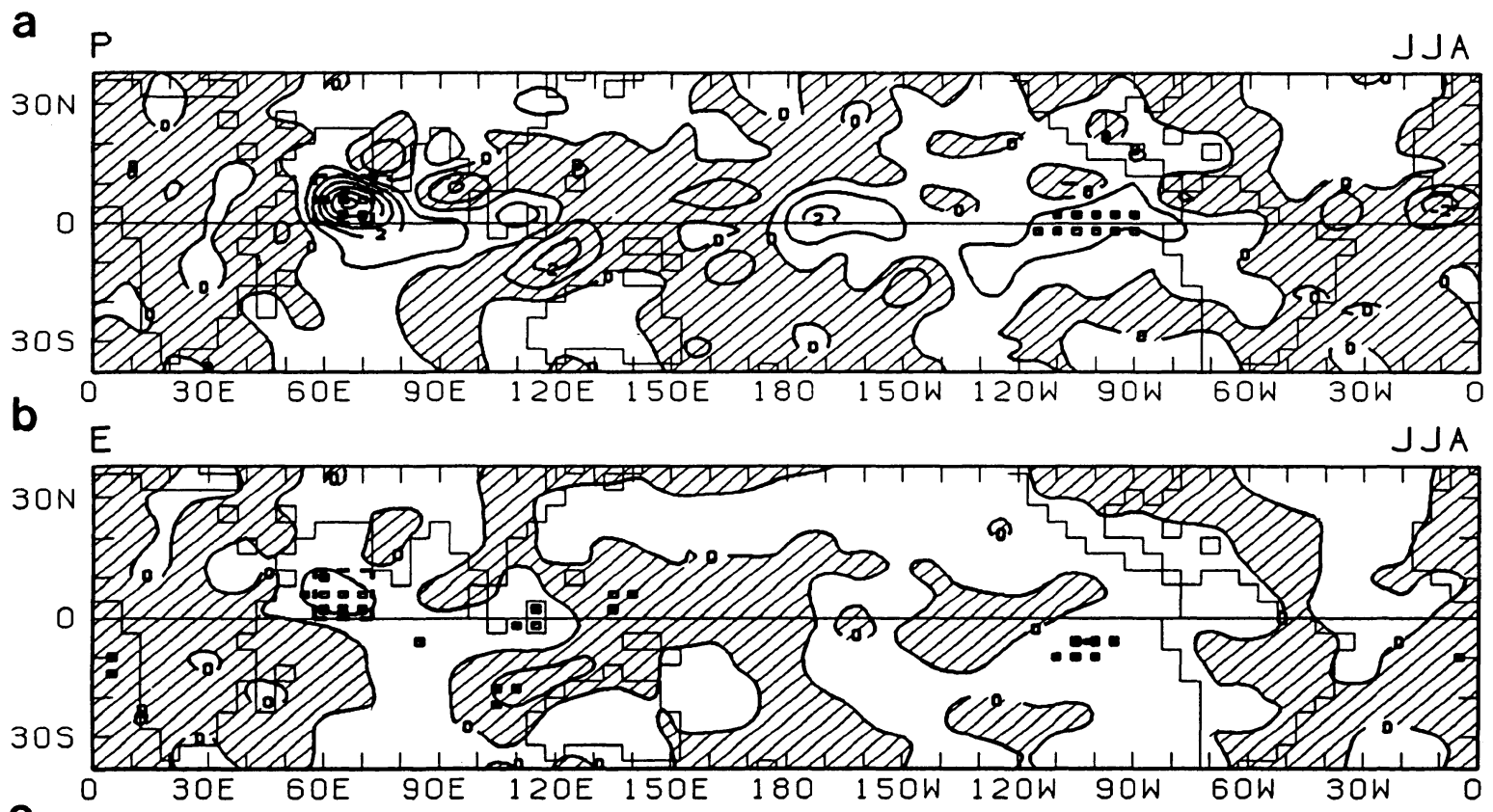

C
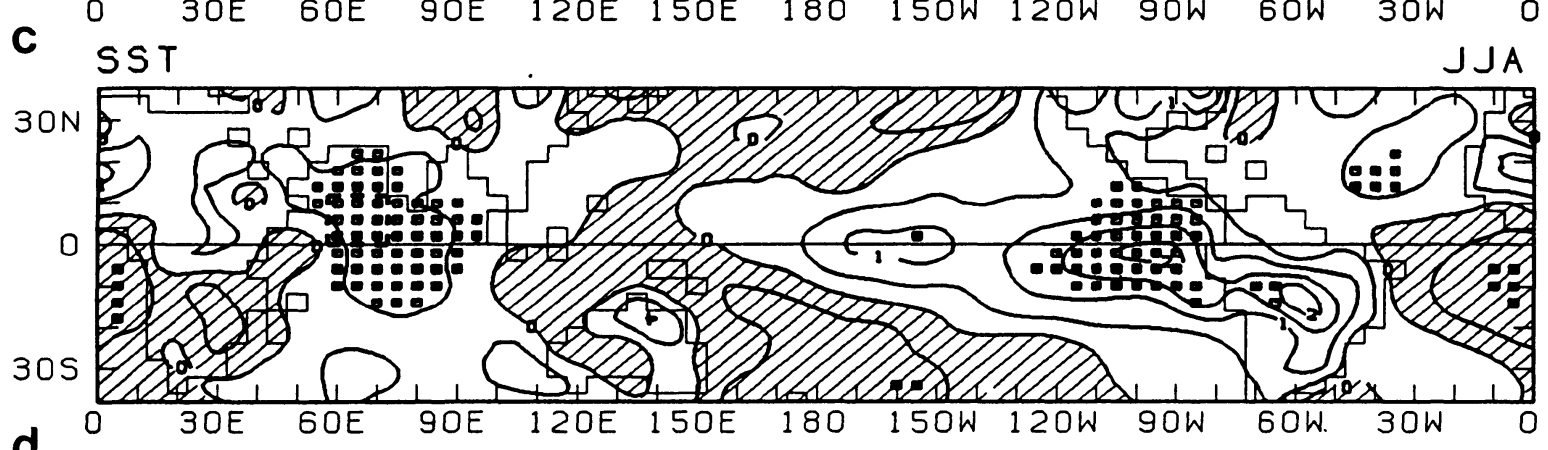

d
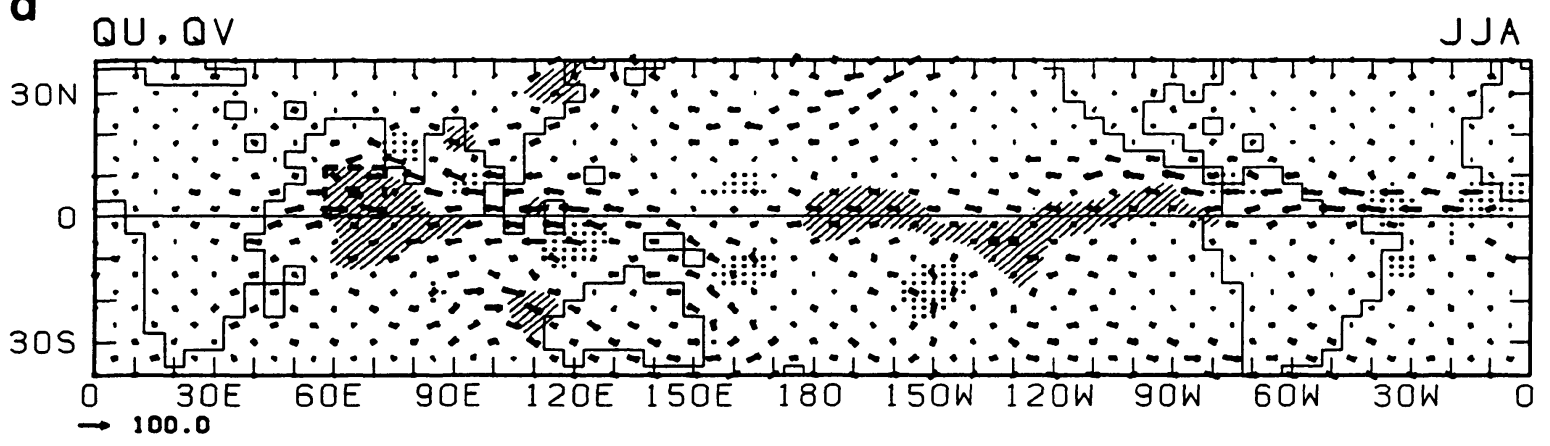

Fig. 8. (a) The composite difference of the JJA mean precipitation for 3 years with the largest precipitation and 3 years with the smallest precipitation in the South Arabian Sea. The contour interval is $1 \mathrm{~mm}$ $\mathrm{d}^{-1}$. Negative values are hatched. Grid points where the simultaneous correlation between the local precipitation anomalies and the precipitation anomalies in the South Arabian Sea is significant at the $95 \%$ level are indicated by dots. (b) As in (a) except for the evaporation. (c) As in (a) except for the SST. The contour interval is $0.5^{\circ} \mathrm{C}$. (d) As in (a) except for the moisture flux. The reference vector is $100 \mathrm{~kg} \mathrm{~m}^{-1} \mathrm{~s}^{-1}$. Regions with the moisture flux convergence greater than $1 \mathrm{~mm} \mathrm{~d}^{-1}$ are hatched and those less than $-1 \mathrm{~mm} \mathrm{~d}^{-1}$ are dotted.

the precipitation in the South Arabian Sea is anomalously large, the westerly moisture flux over the Arabian Sea shifts further southward than normal. Therefore, the westerlies which hit the Indian subcontinent are weaker and the precipitation over India is less than normal. There is also an anomalous easterly moisture flux from the maritime continent into the Indian Ocean where the SST is warmer than normal, contributing to the anomalous precipitation in the equatorial Indian Ocean. A large anomalous easterly moisture flux from the equatorial Atlantic to the eastern Pacific accounts for the precipitation 
Table 2. The lagged correlations between the seasonal mean SST in the NINO3 region $\left(150^{\circ} \mathrm{W}-90^{\circ} \mathrm{W}\right.$, $\left.4^{\circ} \mathrm{S}-4^{\circ} \mathrm{N}\right)$ and the simulated seasonal mean precipitation in (a) the South Arabian Sea $\left(57.5^{\circ} \mathrm{E}-72.5^{\circ} \mathrm{E}\right.$, $\left.0^{\circ} \mathrm{N}-12^{\circ} \mathrm{N}\right)$, (b) the Bay of Bengal $\left(82.5^{\circ} \mathrm{E}-97.5^{\circ} \mathrm{E}, 4^{\circ} \mathrm{N}-16^{\circ} \mathrm{N}\right)$ and (c) the Australian monsoon region $\left(122.5^{\circ} \mathrm{E}-137.5^{\circ} \mathrm{E}, 12^{\circ} \mathrm{S}-0^{\circ} \mathrm{S}\right)$. All seasons' data are used.

(a) South Arabian Sea precipitation vs. NINO3 SST

\begin{tabular}{|c|c|c|c|c|c|c|c|c|c|c|c|c|c|c|c|c|}
\hline & \multicolumn{7}{|c|}{$\begin{array}{c}\text { South Arabian Sea } \\
\text { precipitation leads NINO3 SST }\end{array}$} & & \multicolumn{8}{|c|}{$\begin{array}{c}\text { South Arabian Sea } \\
\text { precipitation lags NINO3 SST }\end{array}$} \\
\hline $\begin{array}{l}\text { lag } \\
\text { (season) }\end{array}$ & 8 & $\begin{array}{ll}7 & 6\end{array}$ & 5 & 4 & 3 & 2 & 1 & 0 & 1 & 2 & 3 & 4 & 5 & 6 & 7 & 8 \\
\hline $\begin{array}{l}\text { correlation } \\
(\%)\end{array}$ & -9 & $-12-15$ & -20 & -20 & -9 & 6 & 10 & 13 & 14 & 24 & 32 & 23 & 24 & 9 & 3 & -7 \\
\hline
\end{tabular}

(b) Bay of Bengal precipitation vs. NINO3 SST

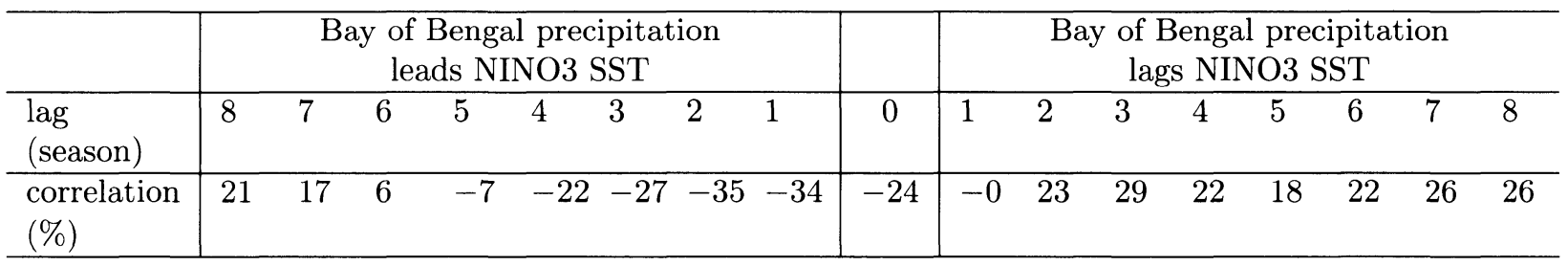

(c) Australian summer precipitation vs. NINO3 SST

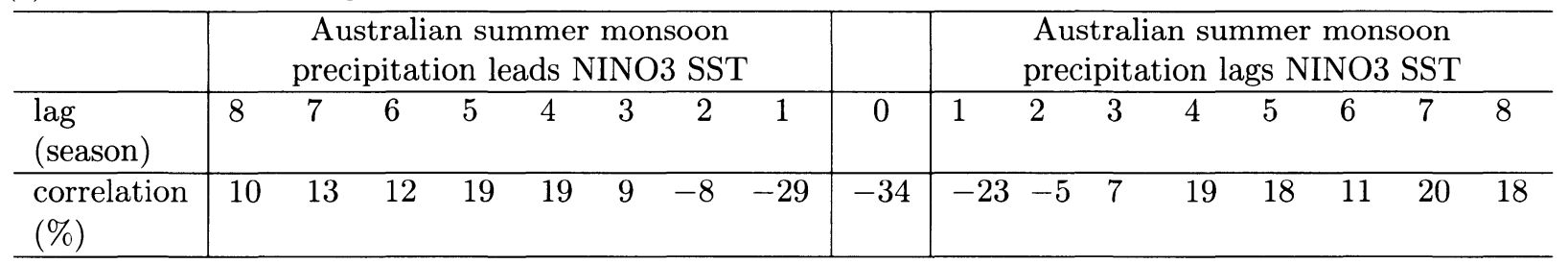

anomalies in these regions.

\section{2) INDIAN SUBCONTINENT}

Figure 9 shows the composite maps for the precipitation over the Indian subcontinent. Data for 3 years with the largest precipitation (1973, 1985 and 1984 model year) and 3 years with the least precipitation (1979, 1987 and 1983) are composited. This composite is nearly the mirror image of Fig. 8. That is, the simulated precipitation over India is negatively correlated with that over the South Arabian Sea. There are significant large negative SST anomalies over the Indian Ocean and over the eastern equatorial Pacific. The ground temperature anomaly is negative over India because the increased cloud reflects the solar insolation reaching the ground. The lower tropospheric westerlies over the Arabian Sea shift further northward than normal and there is an anomalous cyclonic circulation over the subcontinent.

The above two cases are consistent in the context of having an anomalous cyclonic (anticyclonic) circulation and a southward (northward) shift of surface westerlies over the South Arabian Sea when the SST there are above (below) normal. Therefore, the simulated interannual variation of the Indian pre- cipitation is very closely connected with the circulations in the Arabian Sea and the $\mathrm{SS}^{\prime} \Gamma$ there.

\section{3) BAY OF BENGAL}

Figure 10 shows the composite maps for the Bay of Bengal precipitation. This region is where the model precipitation is the largest in its interannual variation, along with the South Arabian Sea. Data for 3 years with the largest precipitation (1988, 1978 and 1981 model year) and 3 years with the least precipitation (1972, 1971 and 1982) are composited.

When the Bay of Bengal precipitation is larger than normal, precipitation tends to be above-normal in the western Pacific and below-normal in the eastern Pacific, reflecting the SST anomalies there. The evaporation composite in the Bay of Bengal is significantly positive but its magnitude is much smaller than the precipitation. Therefore, the anomalous moisture flux convergence into this region is much more responsible than the local evaporation for the interannual variability in precipitation. The SST map shows that the simulated precipitation in the Bay of Bengal is highly positively correlated with the western Pacific SST and negatively correlated with the eastern Pacific SST.

It should be noted that the in situ SST anomaly 
a $\mathrm{P}$

\lrcorner$\lrcorner A$
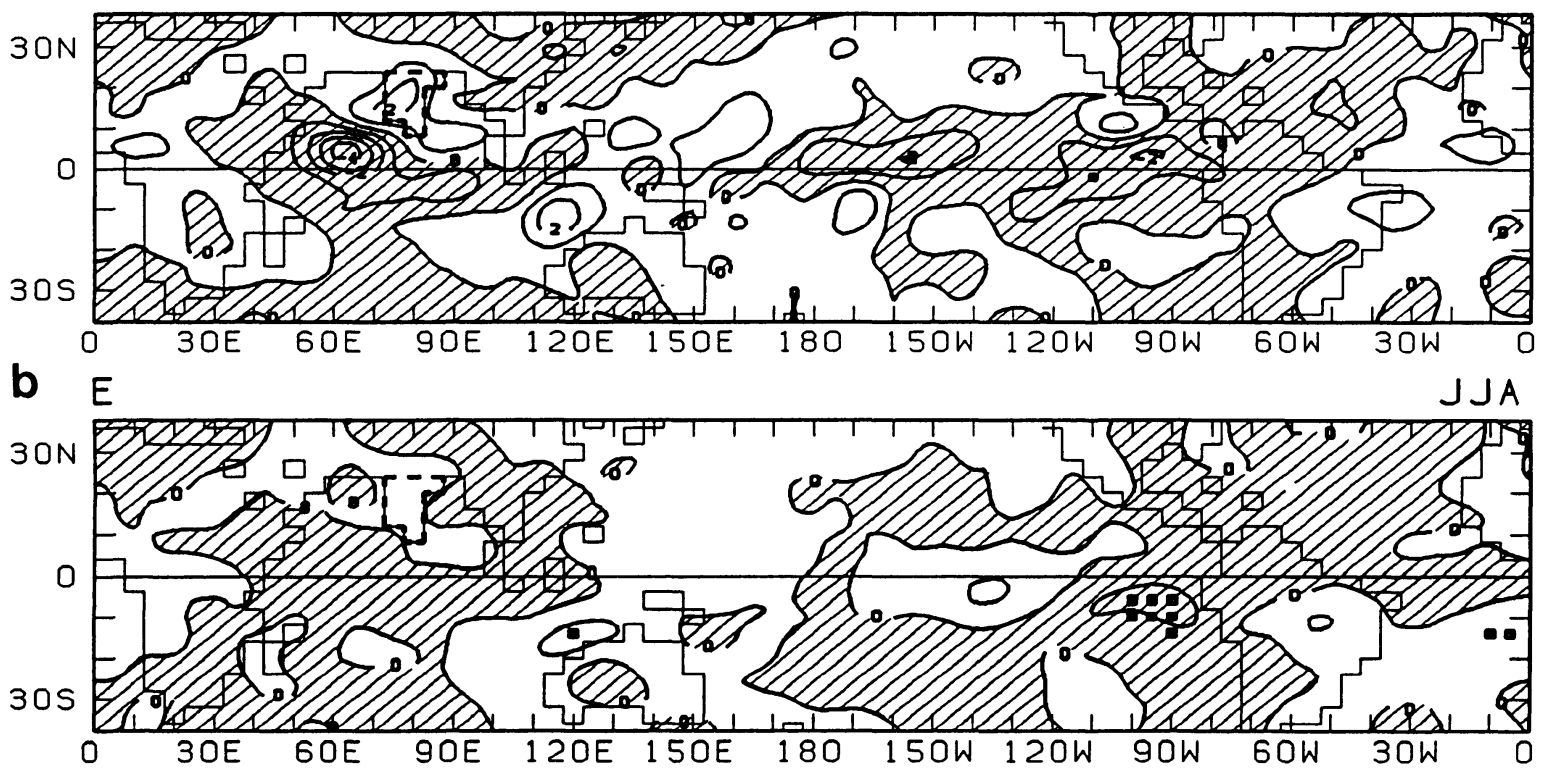

C SST

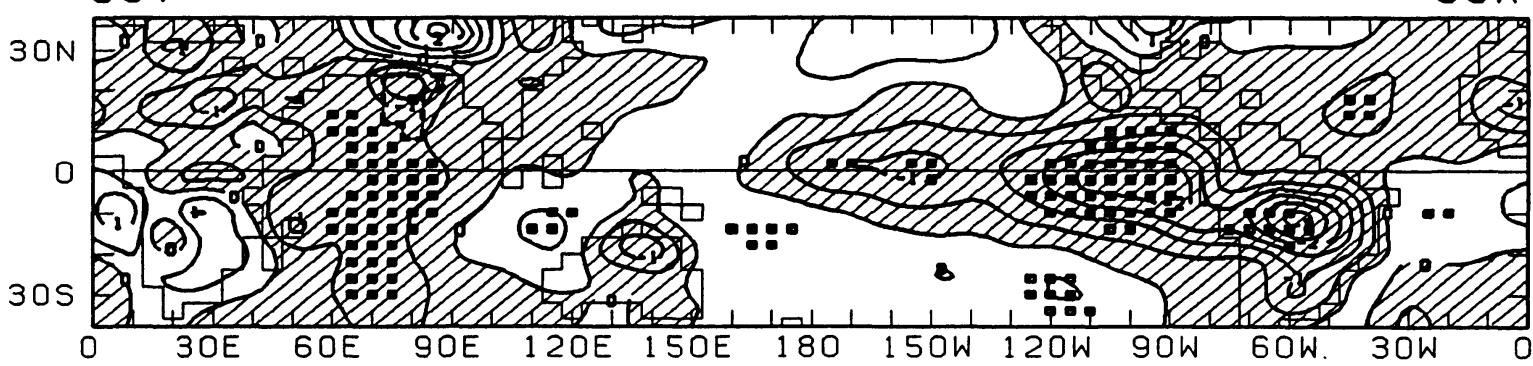

d QU,QV

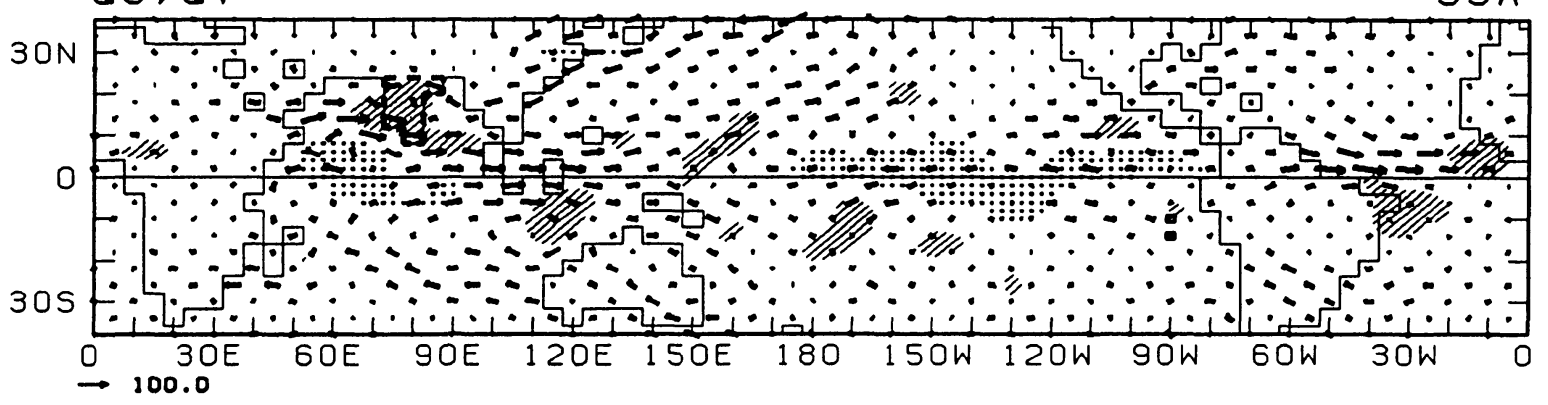

Fig. 9. As in Fig. 8 except for the Indian subcontinent.

is small and shows an insignificant relationship with the Bay of Bengal precipitation. The anomalous moisture flux is characterized by a significant converging flow (when the precipitation in the Bay of Bengal is above normal) toward the maritime continent. The positive SST anomalies over the western Pacific are directly responsible for this anomalous flow. This large-scale circulation feature is responsible for the positive precipitation anomaly over the Bay of Bengal and over the western Pacific, and the negative precipitation anomaly over the eastern Pacific. In addition to this large-scale feature, the anomalous moisture flux shows a distinct meridional component over the Indian Ocean north of the equator, resulting a strong cyclonic curvature of the flow at the southern tip of the Indian subcontinent. The southerly flux component that is the maximum to the south of the region and the westerly component that is the maximum to the west of the region are responsible to the anomalous positive precipitation over the Bay of Bengal. The moisture source of the anomalous precipitation over the Bay of Bengal, other than the local evaporation, comprises of the westerly flux from the Arabian Sea and the crossequatorial southerly flux from south of the region. The warmer than normal SST in the maritime continent may be responsible for the intensified monsoon circulation throughout South Asia with large 
a $\mathrm{P}$

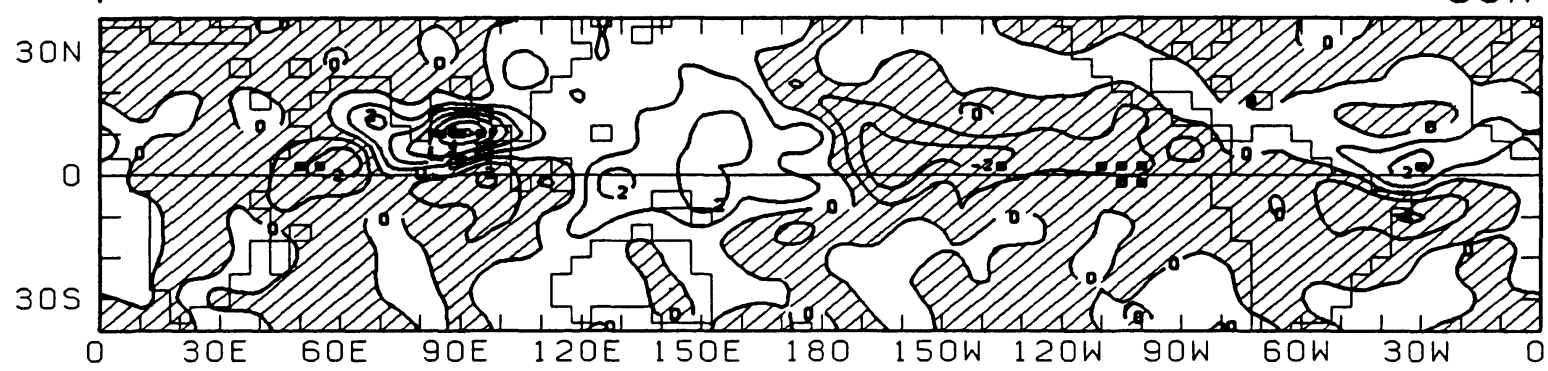

b $E$

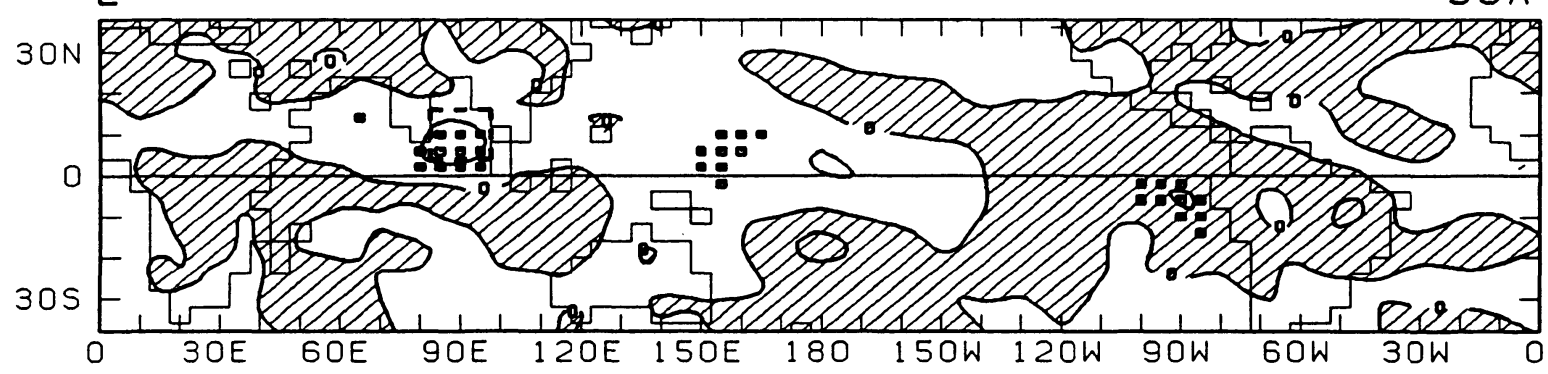

C SST

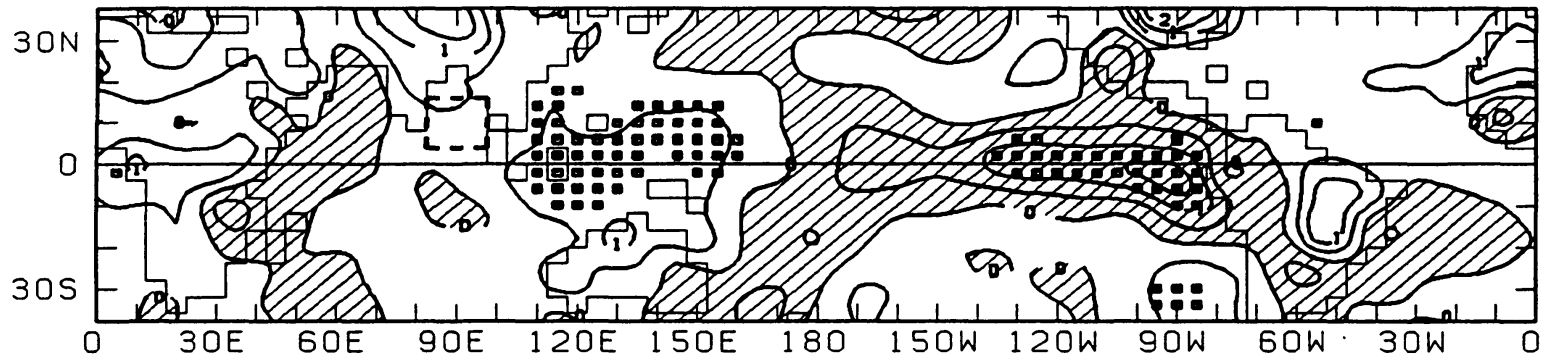

d QU,QV

JJA

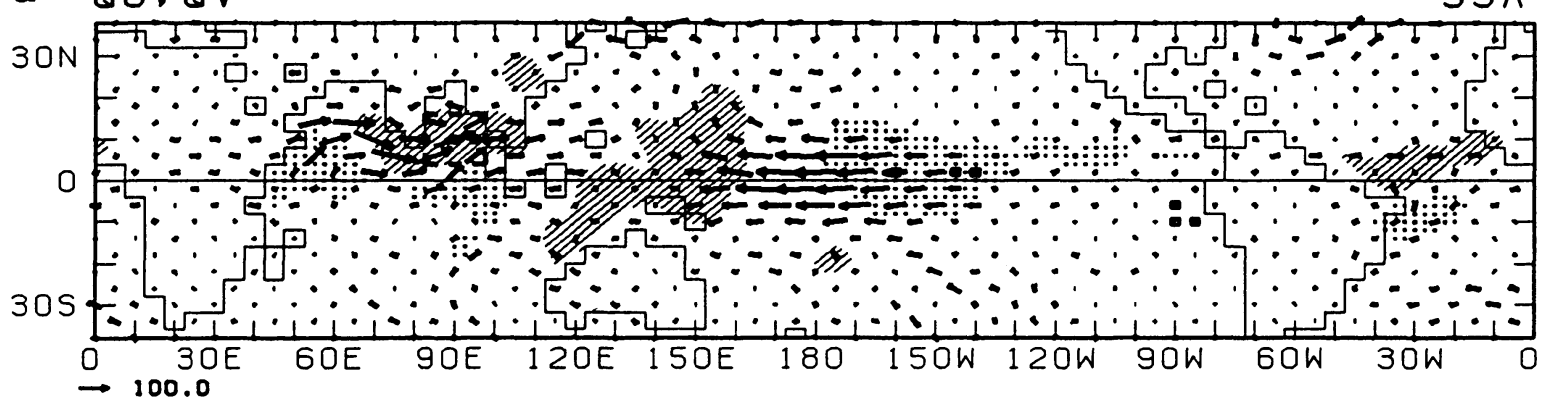

Fig. 10. As in Fig. 8 except for the Bay of Bengal.

anomalous precipitation over the Bay of Bengal.

The lagged correlation between the NINO3 SST and the Bay of Bengal precipitation is shown in Table $2 \mathrm{~b}$. The correlation is large with $r=-0.35$ when the precipitation leads the eastern Pacific SST for 2 seasons. Figure 11 shows the simulated JJA precipitation anomaly (normalized by its standard deviation) in the Bay of Bengal for each year and the NINO3 SST anomaly 6 months later. The correlation coefficient between them is $r=-0.47$ and is statistically significant. Table $2 \mathrm{~b}$ also shows a positive correlation of +0.29 when the Bay of Bengal precipitation lags the NINO3 SST for 3 seasons but with a smaller magnitude than the precipitation leads the
SST. This feature is similar to the relationship between the observed Indian monsoon rainfall and the central equatorial Pacific SST (Yasunari, 1990).

\section{The Australian summer monsoon}

a. Mean and standard deviation

Figure 12 shows the 20-year mean DJF precipitation and its standard deviation in the observed SST run. The heavy precipitation is found in South America, South Africa and the Australian monsoon region from Indonesia to Australia. The South Pacific Convergence Zone (SPCZ) extends southeast compared to the JJA season.

Figure 13 shows the total column moisture flux 


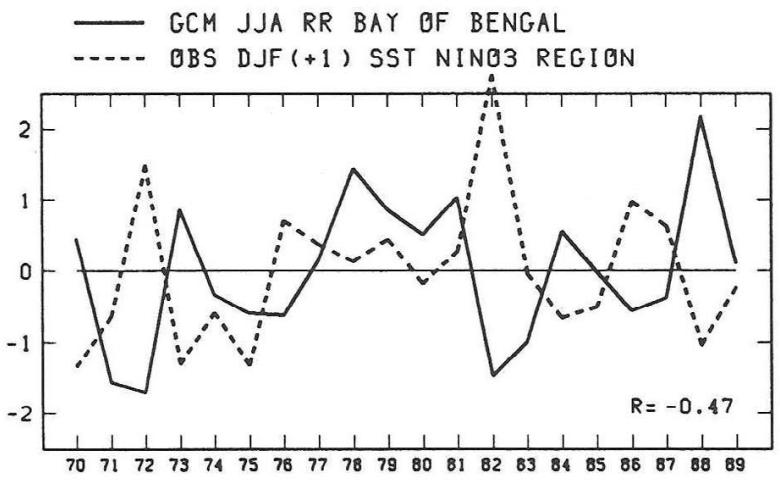

Fig. 11. Time-series of the normalized anomalies of the simulated JJA precipitation in the Bay of Bengal (solid line) and the observed DJF sea surface temperature in the NINO3 region 6 months later (dashed line).

in this season. The salient features of the simulated moisture flux correspond to the observed lower tropospheric wind field during the Australian summer monsoon (Murakami and Sumi, 1982). In the Australian monsoon region, there is a cyclonic circulation with its center to the northwest of Australia (around $125^{\circ} \mathrm{E}, 14^{\circ} \mathrm{S}$ ). Corresponding to this system, there is a precipitation peak due to convergence by the westerly moisture flux south of the equator from Indonesia to New Guinea. This moisture flux originates partly from off the west coast of Australia, transported by the cyclonic flow, and partly from the Northern Hemisphere by the crossequatorial northerly flow both at $85^{\circ} \mathrm{E}$ and at $105^{\circ} \mathrm{E}$ before merging into the westerly flow to the south of Indonesia. Other large northerly cross-equatorial moisture flux is located at the east coast of Africa and the inland Amazon basin. In northeast Australia, the moisture flux convergence of the easterly trades from the South Pacific is responsible for the precipitation maximum there. The other precipitation maxima in South America and South Africa are also compensated by the easterly moisture flux convergence from the Atlantic and the Indian Ocean, respectively.

The interannual variability in precipitation (Fig. 12 bottom) is particularly large over the ocean between Indonesia and New Guinea. The moisture flux also shows a large variability there. There is a secondary peak in precipitation variability east of New Guinea. Over the islands in the maritime continent, the interannual variation is rather smaller than the surrounding oceans, although the mean precipitation is of comparable magnitude. Similarly, the standard deviation is not so large over the land of South America, South Africa and northeast Australia, as is true in the JJA season.

\section{b. Interannual variation}

Figure 14 shows the DJF mean anomalous precipitation, the evaporation, the SST, and the moisture flux and its convergence/divergence composited about the precipitation in the Australian monsoon region. The $15^{\circ} \times 12^{\circ}$ area centered at $130^{\circ} \mathrm{E}, 6^{\circ} \mathrm{S}$ between Indonesia and New Guinea (the Australian Mediterranean Sea), where there is a large interannual variability in the precipitation (Fig. 12), is defined as the Australian monsoon region in the present study. Data for 3 years with the largest
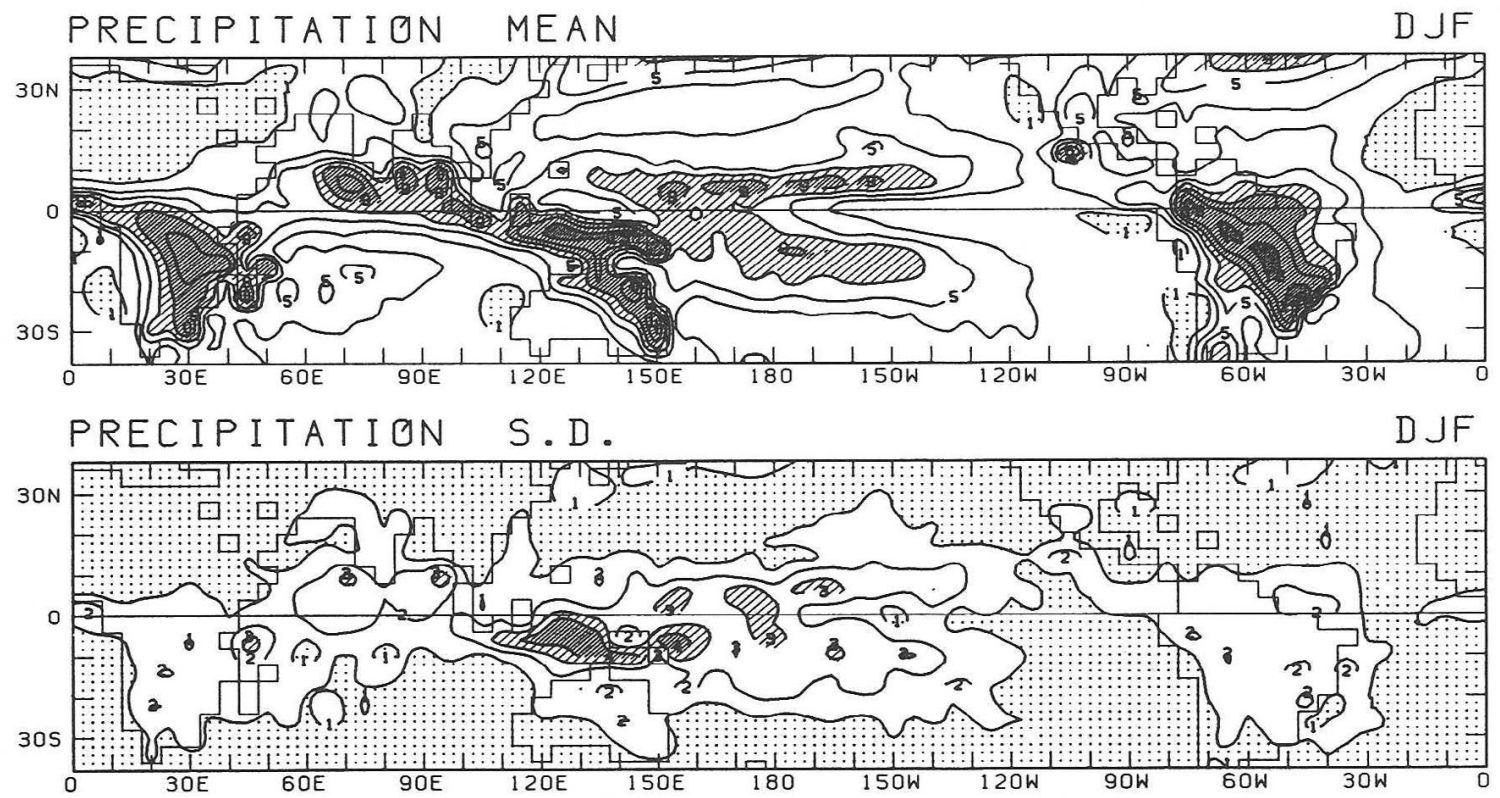

Fig. 12. As in Fig. 4 except for the DJF season. 

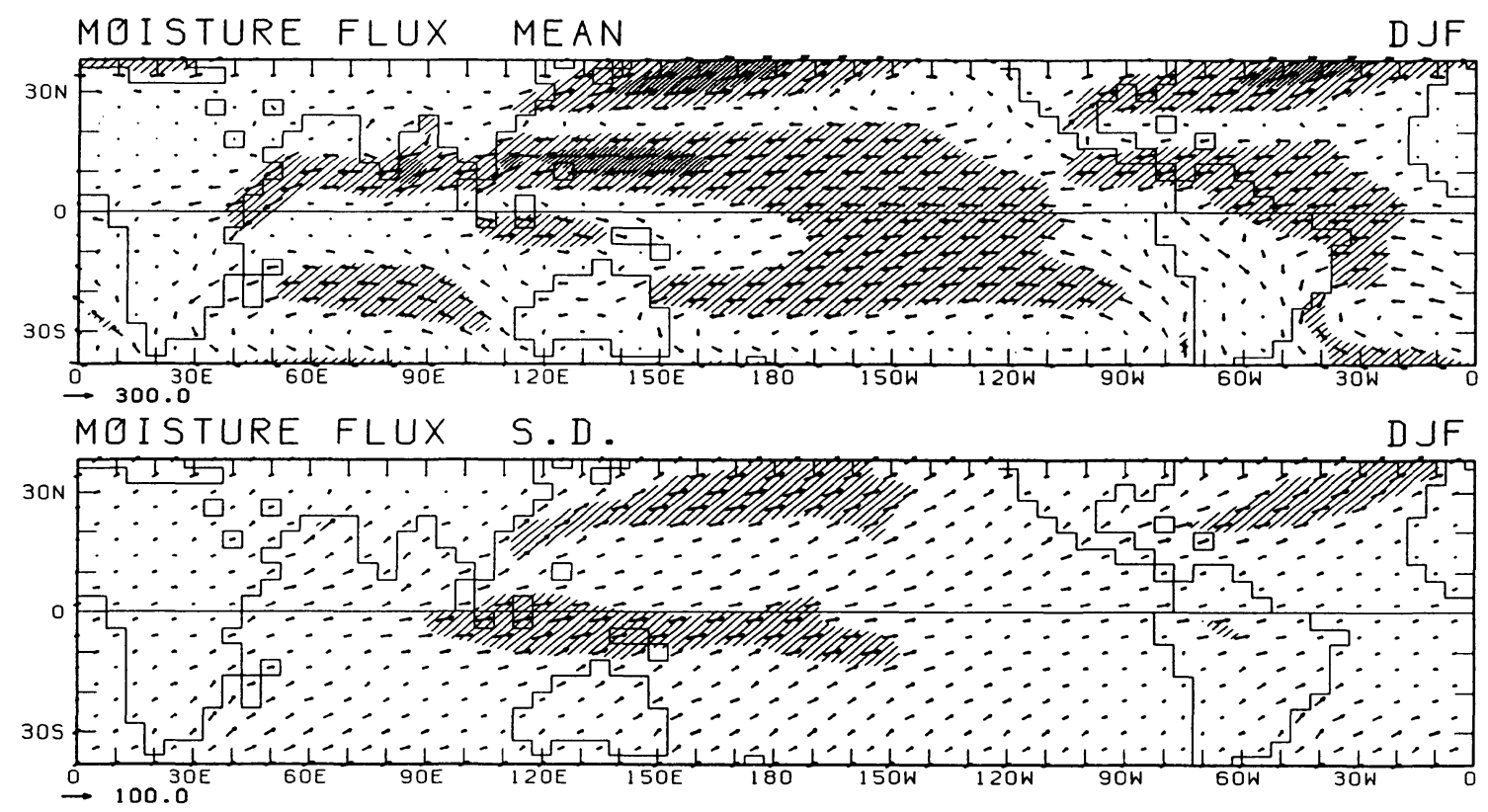

Fig. 13. As in Fig. 5 except for the DJF season.

precipitation (DJF in 1970/71, 1983/84 and 1986/87 model years) and 3 years with the least precipitation $(1972 / 73,1979 / 80$ and $1984 / 85)$ are composited.

When the precipitation in the reference region is large, there tends to be anomalous precipitation with the same polarity at and around New Guinea. The area with the reversed polarity is located east of the dateline, over the Indian Ocean south of the equator and over the Bay of Bengal, although they are not significant. The magnitude of the anomalous evaporation in the reference region is small in spite of significant correlation with the precipitation.

Highly significant is the anomalous westerly moisture flux west of the reference region from the central Indian Ocean to Indonesia south of the equator, and the anomalous easterly moisture flux near the dateline. There is small but significant anomalous easterly moisture flux over and to the west of Australia at $20^{\circ} \sim 30^{\circ} \mathrm{S}$. The latter suggests an intensification (weakening) of the cyclonic circulation over the Indian Ocean northwest of Australia being related to the heavier (weaker) than normal precipitation in the Australian monsoon region in the model. The northerly moisture flux from India and the Bay of Bengal toward the equator around $80^{\circ} \sim 90^{\circ} \mathrm{E}$ also contributes to larger moisture flux in the maritime continent. This anomalous distribution resembles the theoretical atmospheric response to the tropical heat source (Gill, 1980).

It is shown that the anomalous large moisture surplus (negative $\mathrm{P}-\mathrm{E}$ ) region is located just to the south of Indonesia and this moisture is transported eastward into the reference region. Another moisture source is found over the Bay of Bengal, which indicates the larger role of the northerly cross- equatorial moisture flux than that from the South Indian Ocean. The anomalous moisture surplus over the central equatorial Pacific is transported to the region east of New Guinea. Lubis and Murakami (1984) analyzed the moisture balance during the 1978-79 Australian summer monsoon. They found that the major moisture source regions for the monsoon rainfall are the Indonesian Seas and the subtropical South Pacific off the east coast of Australia and that the contribution of the cross-equatorial moisture flux from the Singapore-Borneo area is less. But the observational study of the interannual variation of the moisture budget for the monsoon rainfall has been sparse.

Figure 14c shows the SST composite concerning the Australian Mediterranean Sea precipitation. The significant positive correlation is found, not on the reference region, but north of the equator in the western Pacific between the Philippines and New Guinea. There are broad regions with negative SST anomalies, though not significant, in the central and the eastern Pacific and in the Indian Ocean. When all seasons' data are used, the lagged correlation between the seasonal mean precipitation in the Australian monsoon region and the NINO3 SST has the maximum negative correlation at no time lag with the correlation coefficient $r=-0.34$ (Table 2c).

\section{Comparison with the observed interannual variations}

The model used is obviously not free from defects. The model resolution is limited. Topography and orography are smoothed according to the resolution. The model has systematic errors. However, it has been shown that there are some significant relation- 
a $\mathrm{P}$

DJF

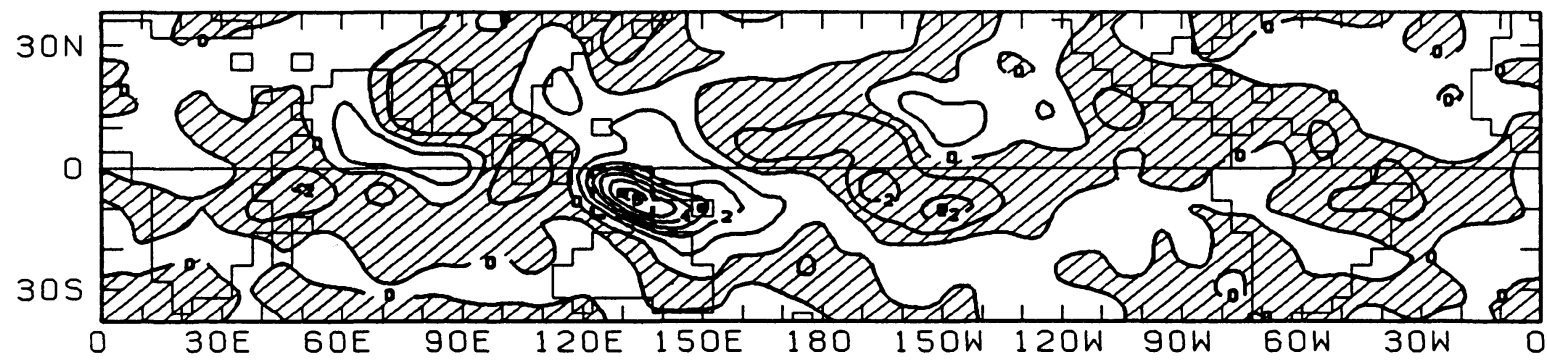

b $E$

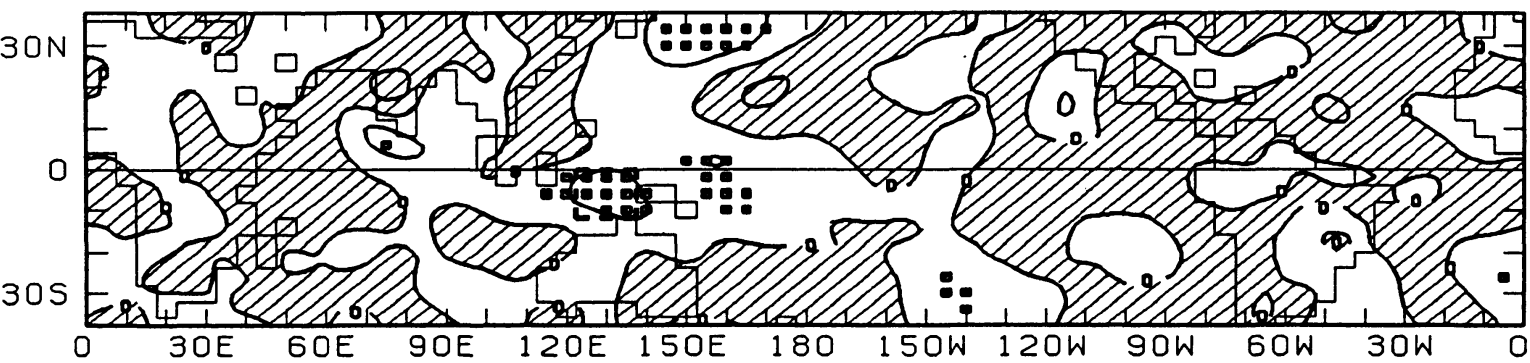

C SST

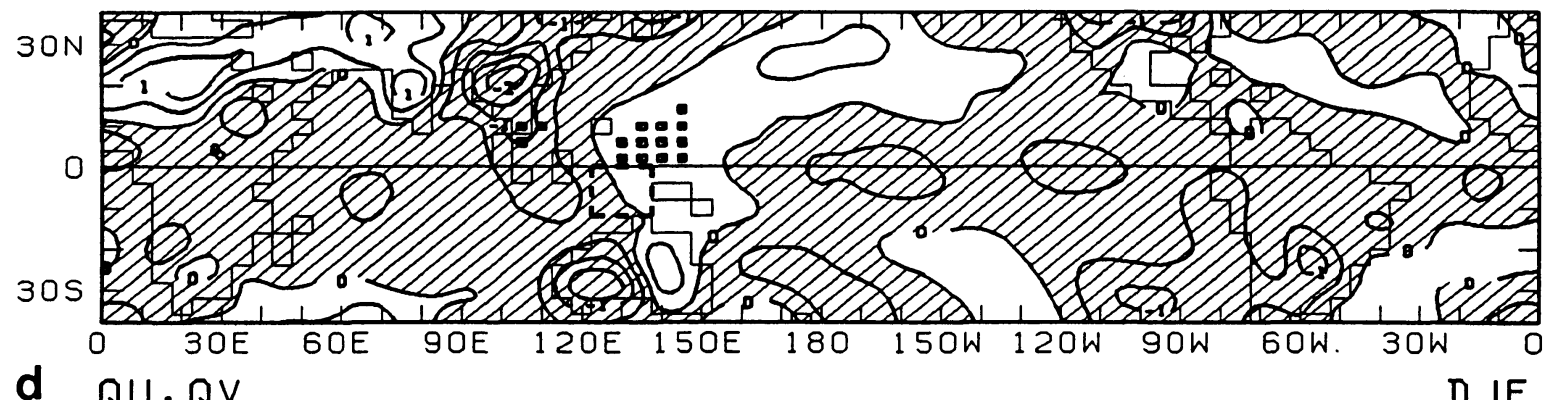

d $Q U, Q V$

D JF

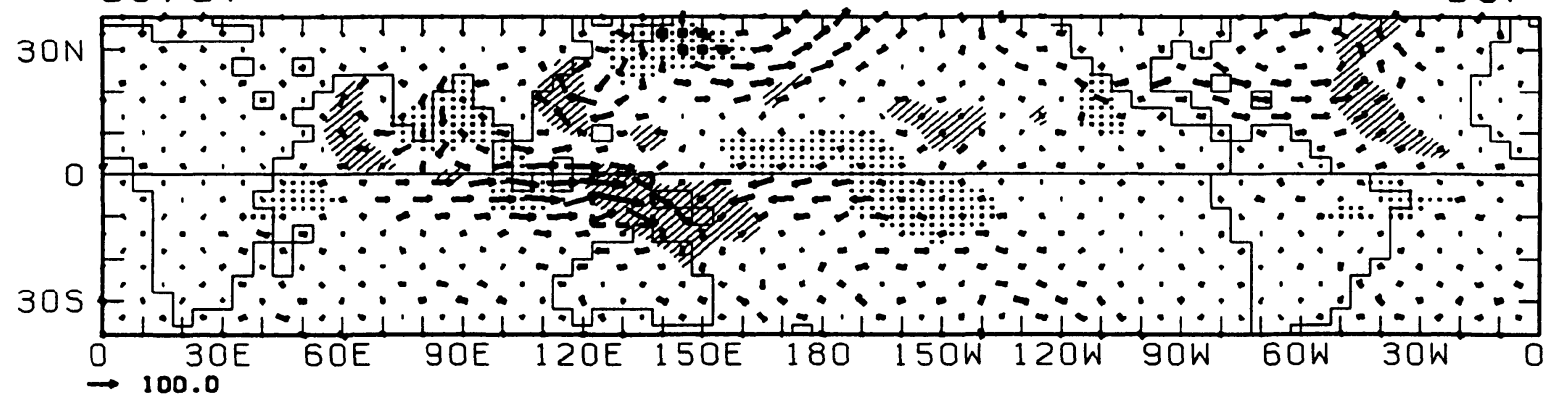

Fig. 14. As in Fig. 8 except for the DJF means for the Australian monsoon region.

ships between the simulated monsoon precipitation and the global SST distribution. This enables us to compare the simulated monsoon precipitation and the observed counterpart. By doing this, we can get some insight into the interannual variations of the tropical atmosphere.

Figure 15 shows the correlations between the observed Indian monsoon rainfall (IMR) for JuneSeptember and the global SST during the period 1970-1986. The IMR index is adopted from Parthasarathy (1987). First, it is noted that the IMR has virtually no correlation with the Indian Ocean SST. Observational and model studies show that the Arabian Sea responds passively to the In- dian monsoon variability; that is, negative SST anomalies follow heavy monsoon rainfall (Shukla, 1987; Dube et al., 1990). The SSTs over the central equatorial Pacific are below normal when the IMR is large, as shown by Shukla (1987) and Yasunari (1990) among others. Moreover, Fig. 15 shows that the SSTs around the Philippines are positively correlated with the IMR (Yasunari, 1990).

The normalized IMR index and the corresponding values obtained by the GCM are shown in Fig. 16 (top). There is no correlation between them. The model does not succeed in simulating the interannual precipitation variability over India. This fact is not surprising when we remember the model res- 


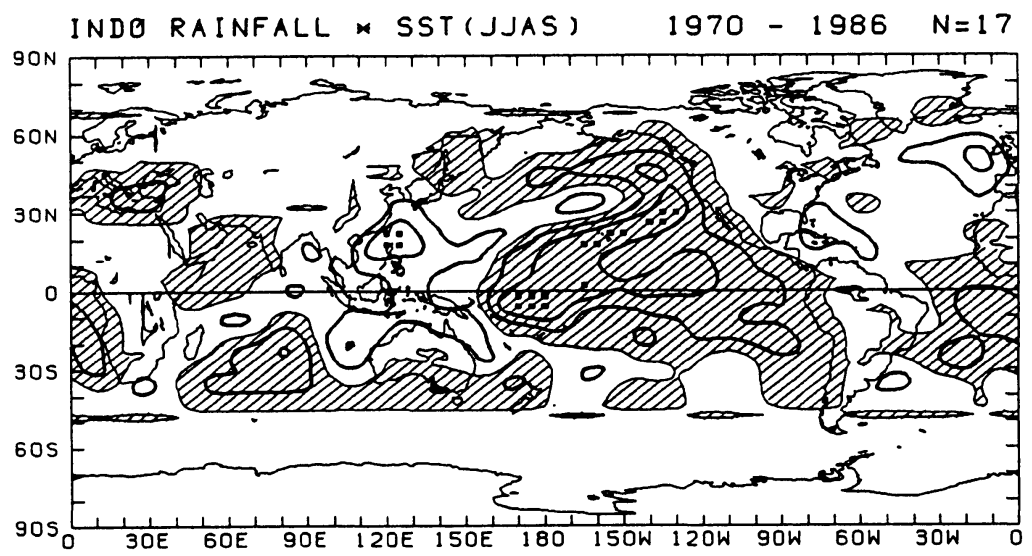

Fig. 15. Correlations between the observed Indian rainfall (Parthasarath, 1987) and the June-September mean SST for the 17-year period 1970-1986. The contour interval is $20 \%$. Negative values are hatched. Significant grid points with the $95 \%$ level are indicated by dots.

- GCM JJAS INDIA -...- OBS JJAS INDIA

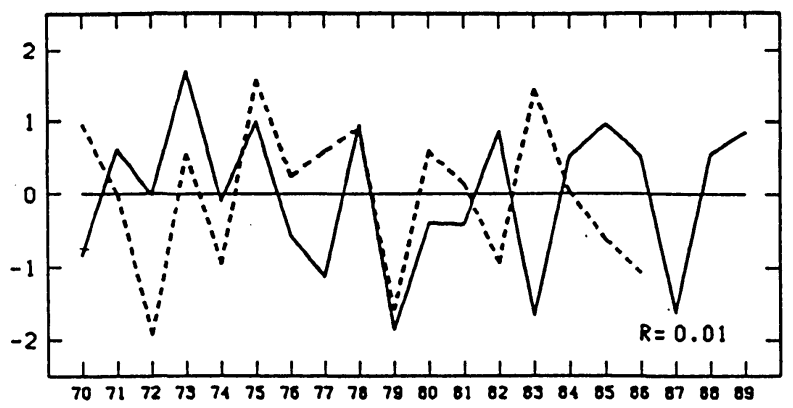

GCM JJAS SOUTH CHINA SEA -..-- OBS JJAS INDIA

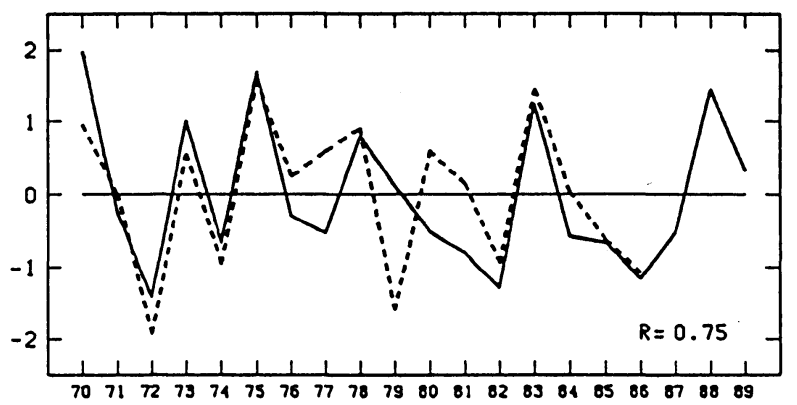

Fig. 16. (top) Time-series of the normalized anomalies of the simulated JuneSeptember precipitation over the Indian subcontinent (solid line) and the observed June-September Indian rainfall (Parthasarath, 1987) (dashed line). (bottom) As in top except for the simulated precipitation in the South China Sea.

olution. As shown in Fig. 9, the simulated precipitation over the Indian subcontinent is correlated with the circulation in the Arabian Sea and not with that in the Bay of Bengal; that is, the precipitation over model India is large when the precipitation in the South Arabian Sea is small, due to a northward shift of the monsoon westerlies. On the other hand, the observed Indian monsoon precipitation is significantly related to the westward-moving monsoon depressions from the Bay of Bengal into the subcontinent (Mooley and Shukla, 1987b). The model used has a horizontal resolution of $5^{\circ} \times 4^{\circ}$ and seems to fail to simulate such depressions.

However, the simulated precipitation in the Bay of Bengal is correlated with the observed IMR with $r=0.42$ (not shown). This suggests that the tendency or the potential of the model atmosphere to produce monsoon depressions whose genesis region is the Bay of Bengal is in some degree simulated by this model. An interesting feature is the model precipitation in the South China Sea. As shown in Fig. 16 (bottom), the simulated precipitation there is significantly correlated with the observed IMR $(r$ $=0.75$ ). The model is responding to the positive SST anomalies in the western Pacific, which tend to appear in the larger IMR years (Fig. 15).

For the DJF season, we show in Fig. 17a the correlations between the observed OLR anomalies averaged over $125^{\circ} \mathrm{E}-135^{\circ} \mathrm{E}, 12^{\circ} \mathrm{S}-0^{\circ} \mathrm{S}$ and the global OLR anomalies. The OLR in the reference region varies concurrently with that in the tropical western Pacific and is negatively correlated with the eastern tropical Pacific OLR. This feature reflects the Pacific-scale SST variations as indicated in Fig. $17 \mathrm{~b}$, which shows the correlation between the reference OLR anomalies and the global SST anomalies. The observed studies show that the northern Australian summer rainfall is below normal when El Niño occurs (McBride and Nicholls, 1983; Ropelewski and Halpert, 1987), although the relationship is the weakest in austral summer.

Figure $17 \mathrm{c}$ is the correlation map between the reference OLR and the simulated precipitation anoma- 
a

OLR (125E-135E.12S-EO) ×OLR DJF OBSERVED $N=10$

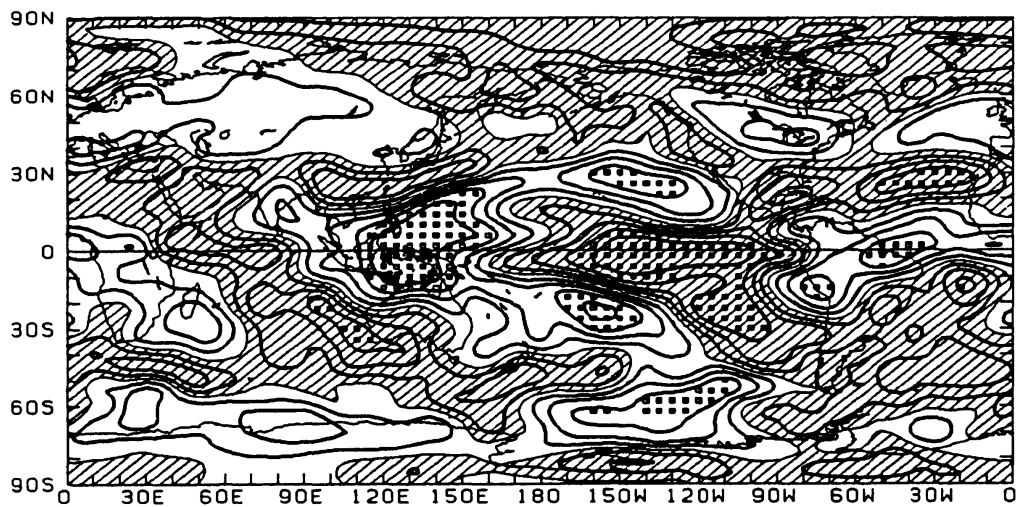

b

OLR(125E-135E,12S-EQ) *SST DJF OBSERVED $N=10$

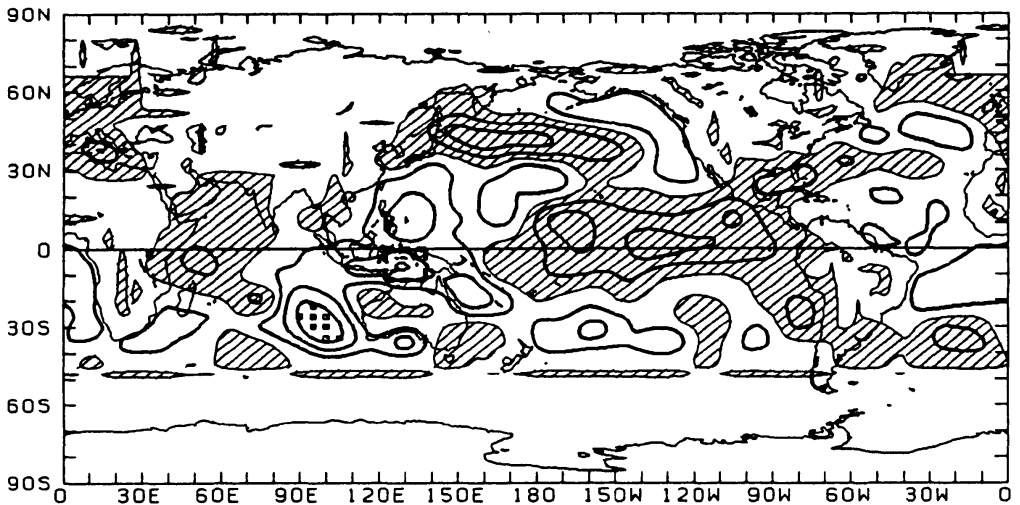

C OLR(125E-135E.12S-ED) $\times G C M R R$ DJF OBSERVED $N=10$

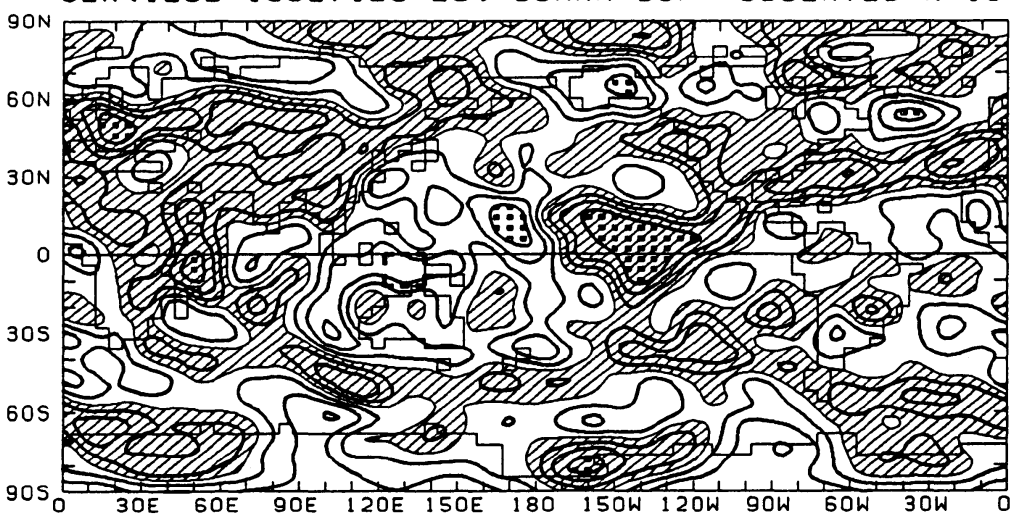

Fig. 17. Correlations between the observed OLR anomalies averaged over $125^{\circ} \mathrm{E}-135^{\circ} \mathrm{E}, 12^{\circ} \mathrm{S}-0^{\circ} \mathrm{S}$ and (a) the OLR anomalies, (b) the SST anomalies and (c) the simulated precipitation anomalies. The DJF mean data are used. The contour interval is $20 \%$. Nagetive values are hatched in (a) and positive values are hatched in (b) and (c).

lies at each grid point. Although the precipitation anomaly in the Australian summer monsoon region used in this study is consistent with the observed convective activities defined by OLR, the correlation is not significant. Overall, there is a precipitation contrast between the western Pacific and the eastern Pacific, corresponding to the SST variations. As indicated in Table 2c, the model can simulate the Australian monsoon variability, which is modestly correlated with the tropical SST changes; that is, the below normal precipitation when El Niño occurs.

To compare the observed rainfall variation and the simulated one globally, observed OLR data is used as a proxy of the observed rainfall. Figure 18 shows the simultaneous correlations between the OLR anomalies and the simulated precipitation anomalies at each grid point for the two extreme seasons. In order to compare large-scale features, $10^{\circ}$ longitude by $8^{\circ}$ 

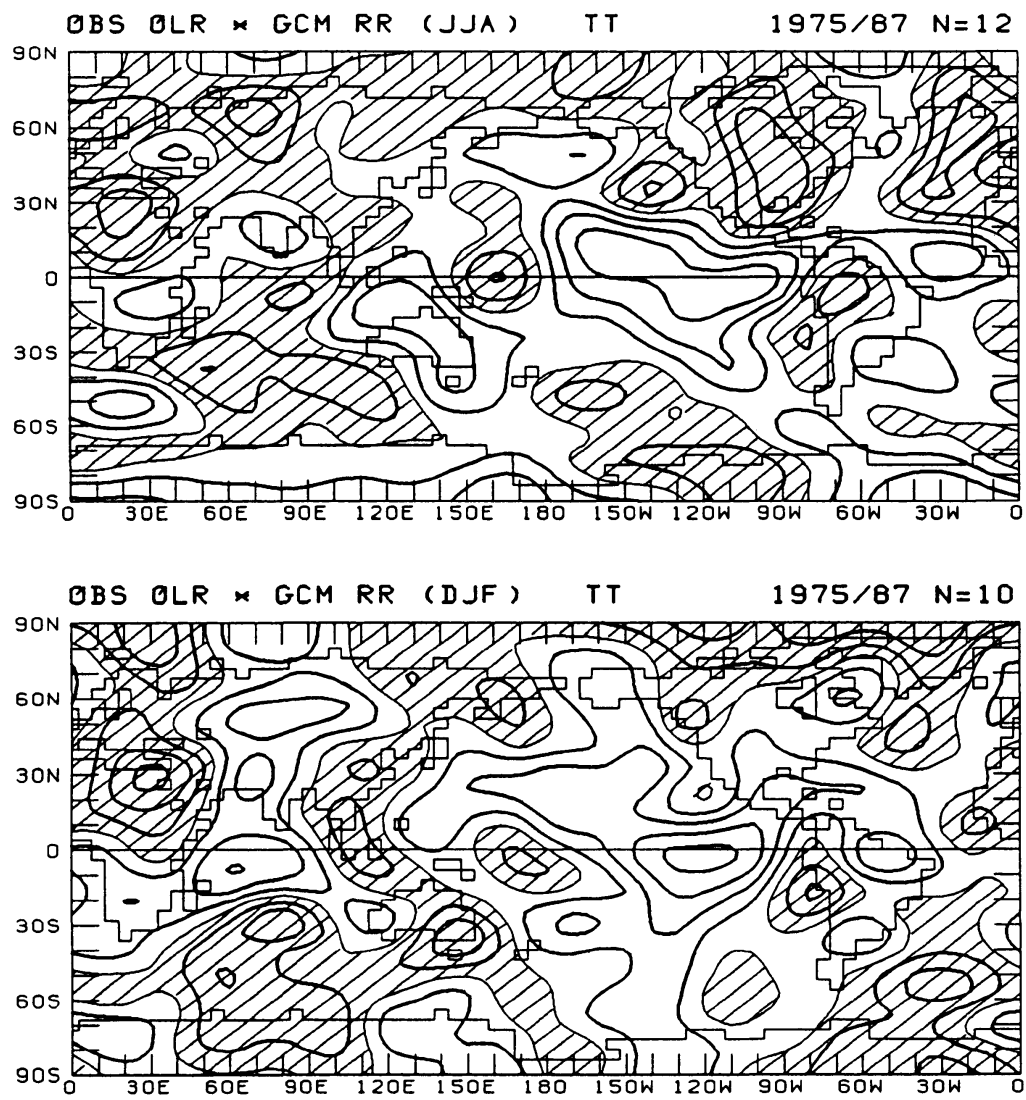

Fig. 18. Correlations between the observed OLR anomalies and the simulated precipitation anomalies for (top) JJA and (bottom) DJF at each $10^{\circ} \times 8^{\circ}$ grid. The contour interval is $20 \%$. Positive values are hatched.

latitude data are made and a 9-point spatial smoothing filter was passed before calculation. The tropical eastern Pacific is the only region with a large negative correlation significant at the $95 \%$ level $(r>0.63$ for northern summer and $r>0.71$ for austral summer). The model is able to respond to the large SST variations in the tropical eastern Pacific with above normal precipitation when the observed OLR is below normal (stronger convective activity). This model capability is as reported by many GCMs so far.

However, the precipitation reproducibility of the model is not satisfactory in other regions, although there may be an uncertainty as to the use of the OLR for the substitute of the precipitation. One possible reason for this discrepancy is that the SST variation is small, particularly in the maritime continent. This may result in a small signal-to-noise ratio. Another reason is that the SST variation is not the sole origin of the atmospheric variability. Simulated land surface conditions, when they are different from the observed, would cause different atmospheric anomalies (Hahn and Shukla, 1976). Moreover, there is a systematic shift of the simulated precipitation pattern from that observed. For example, there is a marked difference between the boreal summers of 1987 and 1988 in the equatorial Pacific (WMO, 1990). The SST difference between 1988 and 1987 is negative eastward of $165^{\circ} \mathrm{E}$ over the equator. The corresponding OLR difference shows a positive anomaly (less convective activity) eastward of about $140^{\circ} \mathrm{E}$ at the equator. The model result (Kitoh, 1991) reveals a considerable eastward shift of these precipitation anomalies. Such a shift can be caused by the systematic error of the model climatology, which is related to the model resolution and parameterizations.

\section{Conclusions}

The interannual variations of the summer monsoon rainfall in the Indo-Australian region simulated by an atmospheric GCM are investigated. The AGCM has been forced by the interannually varying observed SST. It has about a twice-larger standard deviation in precipitation in the tropics compared to the model results forced by the climatological SST. However, the increase in variance is not uniform in the tropics, at least for the precipitation field. The area with the most increased variance is in the eastern equatorial Pacific in JJA, while it is in the central Pacific in DJF, reflecting the seasonal shift of the SST variance pattern. 
The simulated interannual variation of the seasonal mean precipitation is large over the South Arabian Sea and over the Bay of Bengal in JJA and over the oceans north of Australia in DJF. In all these areas, the contribution from the moisture flux convergence is comparable to that due to the local evaporation for the 20-year mean moisture budget. For the interannual variations, on the contrary, the contribution from the moisture flux convergence is dominant in the moisture budget over the local evaporation.

The precipitation in the Bay of Bengal in JJA is found to be significantly correlated with the SST anomalies in the western Pacific, more than with the in situ SST anomalies. The positive SST anomalies in the western Pacific are favorable to the intensified South Asian summer monsoon circulation with strong surface westerlies over the north Indian Ocean. The simulated Bay of Bengal precipitation anomaly and the eastern equatorial Pacific SST anomaly (NINO3 region) have a similar lagged relationship to the observed Indian monsoon rainfall, showing a large negative correlation when the Bay of Bengal precipitation leads the NINO3 SST for 6 months. This suggests that the model has some capability for reproducing the interannual monsoon activities in South Asia by imposing the interannual SST variations, although the precise regional simulation, such as an Indian rainfall, has not been achieved due to the model's limitation (such as a coarse horizontal resolution).

The SST variability over the Indian Ocean, on the other hand, affects the precipitation changes over the South Arabian Sea and the Indian subcontinent. Higher than normal SST is associated with the southward shift of the lower tropospheric monsoon flow, large precipitation over the South Arabian Sea and small precipitation over the Indian subcontinent. In the model atmosphere, the precipitation variability over India is mainly explained by the anomalous moisture flux that hits the subcontinent from the west.

The simulated interannual fluctuation of precipitation over the oceans north of Australia in austral summer is explained mainly by the anomalous westerly moisture flux converging into this region along the Indonesian islands south of the equator. This is accompanied by an intensified cyclonic circulation northwest of Australia, but the cross-equatorial moisture flux from the winter hemisphere, particularly from the Bay of Bengal, is found to be important. An observational study to clarify the interannual moisture budget variations related to the summer monsoon should be done, but would require good quality data on the meridional wind and moisture in the tropics.

The simulated precipitation anomaly and the underlying SST anomaly are not directly related each other on the interannual time-scale even in the tropics, except over the eastern Pacific. Precipitation phenomena in other regions are, therefore, affected not only by the local SST anomaly but also by remote effects such as larger-scale circulation changes induced by the SST anomaly in different places. This teleconnection should be closely related to the basic flow field. Model studies would help us understand this relationship.

\section{Acknowledgments}

I thank an anonymous reviewer, whose critical and valuable comments helped me to improve the original manuscript. This research was a part of "Japanese Experiment on Asian Monsoon (JEXAM)" supported by the Science and Technology Agency. Computations are made with HITAC S-810/10 at MRI.

\section{References}

Alexander, R. C. and R. L. Mobley, 1976: Monthly average sea surface temperature and ice pack limits for 1 deg global grid. Mon. Wea. Rev., 104, 143-148.

Bhaskar Rao, D.V., K. Yamazaki and A. Kitoh, 1991: Some GCM experiments of the Asian summer monsoon related to land boundary conditions. Pap. Met. Geophys., 42, 127-143.

Dube, S.K., M.E. Luther and J.J. O'Brien, 1990: Relationships between interannual variability in the Arabian Sea and Indian summer monsoon rainfall. $\mathrm{Me}$ teor. Atmos. Phys., 44, 153-165.

Gilchrist, A., 1977: The simulation of the Asian summer monsoon by general circulation models. Pure. Appl. Geophys., 115, 1431-1448.

Gill, A.E., 1980: Some simple solutions for heat-induced tropical circulation. Quart. J. Roy. Meteor. Soc., 106, 447-462.

Hahn, D. and J. Shukla, 1976: An apparent relationship between Eurasian snow cover and Indian monsoon rainfall. J. Atmos. Sci., 33, 2461-2463.

Hendon, H.H. and B. Liebmann, 1990: A composite study of onset of the Australian summer monsoon. J. Atmos. Sci., 47, 2227-2240.

Holland, G.J., 1986: Interannual variability of the Australian summer monsoon at Darwin: 1952-82. Mon. Wea. Rev., 114, 594-604.

Jaeger, L., 1976: Monatskarten des Niederschlags fur die ganze Edre. Berichte des Deutschen Wetterdienstes, 18, Nr. 139, Offenbach, W. Germany, 38 pp.

Joseph, R.V., B. Liebmann and H.H. Hendon, 1991: Interannual variability of the Australian summer monsoon onset: possible influence of Indian summer monsoon and El Niño. J. Climate, 4, 529-538.

Kawahara, M., 1990: Interannual and intraseasonal variations of the outgoing longwave radiation. KisyoKenkyu Note, 168, 5-42 (in Japanese).

Kitoh, A., 1991: Interannual variations in an atmospheric GCM forced by the 1970-1989 SST. Part I: Response of the tropical atmosphere. J. Meteor. Soc. Japan, 69, 251-269. 
Kitoh, A. and T. Tokioka, 1986: A simulation of the tropospheric general circulation with the MRI atmospheric general circulation model. Part II: The July performance. Pap. Meteor. Geophys., 37, 145-168.

Krishnamurti, T.N., 1987: Monsoon models. Monsoons. J.S. Fein and P.L. Stephens, Eds., John Wiley \& Sons, New York, 467-522.

Krishnamurti, T.N. and N. Surgi, 1987: Observational aspects of summer monsoon. Monsoon Meteorology. C.P. Chang and T.N. Krishnamurti, Eds., Oxford University Press, 3-25.

Lau, N.-C., 1985: Modeling the seasonal dependence of the atmospheric response to observed El Niños in 1962-76. Mon. Wea. Rev., 113, 1970-1996.

Lubis, S.M. and T. Murakami, 1984: Moisture budget during the 1978-79 Southern Hemisphere summer monsoon. J. Meteor. Soc. Japan, 62, 748-760.

Matthews, E., 1983: Global vegetation and land use: new high resolution data bases for climatic studies. J. Clim. Appl. Meteor., 22, 474-487.

McBride, J.L., 1987: The Australian summer monsoon. Monsoon Meteorology. C.P. Chang and T.N. Krishnamurti, Eds., Oxford University Press, 203-231.

McBride, J.L. and N. Nicholls, 1983: Seasonal relationships between Australian rainfall and the Southern Oscillation. Mon. Wea. Rev., 111, 1998-2004.

Mooley, D.A. and J. Shukla, 1987a: Variability and forecasting of the summer monsoon rainfall over India. Monsoon Meteorology. C.P. Chang and T.N. Krishnamurti, Eds., Oxford University Press, 26-59.

Mooley, D.A. and J. Shukla, 1987b: Characteristics of the westward-moving summer monsoon low pressure systems over the Indian region and their relationship with the monsoon rainfall. Center for Ocean-LandAtmosphere Interactions, October 1987.

Murakami, T. and A. Sumi, 1982: Southern Hemisphere summer monsoon circulation during the 197879 WMONEX. Part I: Monthly mean wind fields. $J$. Meteor. Soc. Japan, 60, 638-648.

Nihoul, J.C.J. (Editor), 1985: Coupled OceanAtmosphere Models. Elsevier Science Publishers, Amsterdam.
Parthasarathy, B., 1987: Droughts/floods in the summer monsoon season over different meteorological subdivisions of India for the period 1871-1984. J. Climatol., 7, 57-70.

Ropelewski, C.F. and M.S. Halpert, 1987: Global and regional scale precipitation patterns associated with the El Niño/Southern Oscillation. Mon. Wea. Rev., 115, 1606-1626.

Shukla, J., 1987: Interannual variability of monsoons. Monsoons. J.S. Fein and P.L. Stephens, Eds., John Wiley \& Sons, New York, 399-466.

Tokioka, T., K. Yamazaki, I. Yagai and A. Kitoh, 1984: A description of the Meteorological Research Institute atmospheric general circulation model (MRI·GCM-I). Tech. Rep. of the MRI, No. 13, 249 pp.

Tokioka, T., K. Yamazaki, A. Kitoh and T. Ose, 1988: The equatorial 30-60 day oscillation and the Arakawa-Schubert penetrative cumulus parameterization. J. Meteor. Soc. Japan, 66, 883-901.

Washington, W.M., 1981: A review of generalcirculation model experiments on the Indian monsoon. Monsoon Dynamics. J. Lighthill and R.P. Pearce, Eds., Cambridge University Press, 111-130.

WMO, 1986: Workshop on comparison of simulations by numerical models of the sensitivity of the atmospheric circulation to sea surface temperature anomalies. WMO/TD-No. 138, WCP-121, 188 pp.

WMO, 1990: Report of the Second Session of the Monsoon Numerical Experimentation Group. WMO/TD-No. 392, WCRP-49.

Yagai, I. and T. Tokioka, 1987: The effect of increased surface drag coefficient over the continents on January circulations. Short- and Medium-Range Numerical Weather Prediction. (T. Matsuno, ed.) Special Volume of J. Meteor. Soc. Japan, 409-419.

Yasunari, T., 1979: Cloudiness fluctuations associated with the Northern Hemisphere summer monsoon. $J$. Meteor. Soc. Japan, 57, 227-242.

Yasunari, T., 1990: Impact of Indian monsoon on the coupled atmosphere/ocean system in the tropical Pacific. Meteor. Atmos. Phys., 44, 29-41.

\section{インドーオーストラリアの夏のモンスーンの年々変動の数值実験}

\section{鬼頭昭雄}

(気象研究所気候研究部)

1970 年から 1989 年までの観測された海面水温を用いて行なった大気大循環モデルの 20 年間の積分結果 からアジアの夏のモンスーン及びオーストラリアの夏のモンスーンの年々変動について調べた。降水量の 年々変動が大きい領域での水蒸気収支に対してそこでの蒸発よりも水蒸気フラックスの収束の役割の方が 大きいため、水蒸気フラックスの変化について詳しく調べた。

北半球の夏のベンガル湾での降水量は、その場の海面水温よりも西部熱帯太平洋でのそれとよい相関が ある。西部熱帯太平洋での正の海面水温偏差は強い南アジアの夏のモンスーンに有利で、北インド洋では 
強い西風を伴っている。モデル中のインドの雨はアラビア海の雨と逆相関にあり、これはアラビア海上の 下層風の南北の位置と関倸している。南半球の夏のオーストラリアの北の海域での降水量変動は、この海 域に流入する西からの水蒸気フラックスで説明される。これはオーストラリア北西方での低気圧性循環を 伴っているが、冬半球からの赤道を越えた水蒸気フラックスが重要である。観測とのいくつかの比較を行 ない、モデル結果と観測との違いについても議論した。 